\title{
Contribuição dos processos magmáticos e tectono-metamórficos na gênese dos minérios sulfetados de Ni-Cu de Mangabal I e Mangabal II, Goiás, Brasil
}

\author{
Contribution of magmatic and tectono-metamorphic processes in the genesis \\ of the Ni-Cu sulfide ores from Mangabal I and Mangabal II, Goiás, Brazil
}

\author{
Bruno Venancio da Silva ${ }^{1}$ (D), Filipe Goulart Lima², Rafael Rodrigues de Assis $^{3}$ (1), \\ Antenor Zanardo ${ }^{1}$, Daniel Françoso de Godoy ${ }^{1}$ (i) \\ 'Universidade Estadual Paulista "Júlio de Mesquita Filho" - Unesp, Instituto de Geociências e Ciências Exatas, Avenida 24A, \\ 1.515, CEP 13506-900, Vila Bela Vista, Rio Claro, SP, BR (rochabt@gmail.com; azanardo@rc.unesp.br; dfgodoy@gmail.com) \\ ${ }^{2}$ Universidade Federal de Uberlândia - UFU, Instituto de Geografia, Monte Carmelo, MG, BR. (filipeglima@yahoo.com.br) \\ 3Universidade de São Paulo - USP, Instituto de Geociências, Departamento de Geologia Sedimentar e Ambiental, São Paulo, \\ SP, BR (rafael.assiss@gmail.com)
}

Recebido em 31 de dezembro de 2017; aceito em 17 de dezembro de 2019

\begin{abstract}
Resumo
Os complexos estratiformes Mangabal I e Mangabal II fazem parte de um conjunto de intrusões máfico-ultramáficas sinorogênicas, brasilianas, que ocorrem na região central do Brasil. Neste trabalho, são apresentados novos dados petrográficos e de microscopia eletrônica de varredura dos sulfetos de $\mathrm{Ni}-\mathrm{Cu}$ de ambos os complexos. Em um litotipo com textura cumulática preservada, ocorrem as associações pirrotita-pentlandita e pirrotita-pentlandita-calcopirita na forma de glóbulos de sulfetos intercumulus. A pirrotita apresenta conteúdos de ferro entre 64,9 e $65,5 \%$, a pentlandita apresenta conteúdos de níquel entre 14,6 e $25,3 \%$ e a calcopirita apresenta conteúdos de cobre entre 29,1 e $31,5 \%$. Nos litotipos intensamente transformados pelo metamorfismo e que não preservam textura ígnea, ocorrem as associações pirrotita-pentlandita, pirrotita-pentlandita-calcopirita e pirrotita-pentlandita-calcopirita-pirita, todas associadas a concentrações variadas de rutilo. Essas associações apresentam pirrotita com conteúdos de ferro entre 59,1 e 62,1\%, pentlandita com conteúdos de níquel entre 15 e $40 \%$ e calcopirita com conteúdos de cobre entre 32,9 e 36,6\%. A associação pentlandita-pirita, bem como vênulas compostas de pirita ou calcopirita, constituem fases de substituição e remobilização dos sulfetos preexistentes. Baseando-se na mineralogia, na textura e nos conteúdos de metais base, observa-se que as associações de sulfetos encontradas nos litotipos intensamente transformados pelo metamorfismo são semelhantes em ambos os complexos e diferem das associações encontradas no litotipo que preserva textura ígnea. Dessa forma, sugere-se que os processos tectono-metamórficos atribuídos ao Ciclo Brasiliano ocasionaram remobilizações e mudanças químicas nos sulfetos de Ni-Cu dos complexos Mangabal I e Mangabal II.
\end{abstract}

Palavras-chave: Complexos máfico-ultramáficos; Ciclo Brasiliano; Faixa Brasília; Sulfeto de Ni e Cu; Remobilização de minério; Rutilo.

\begin{abstract}
The Mangabal I and Mangabal II layered complexes are part of a set of mafic-ultramafic synorogenic intrusions emplaced during the Brasiliano orogenic Cycle in central Brazil. In this work, new petrographic and scanning electron microscopy data of $\mathrm{Ni}-\mathrm{Cu}$ sulfides of both complexes are presented. A well-preserved, igneous cumulate textured rock has pyrrhotite-pentlandite and pyrrhotite-pentlandite-chalcopyrite assemblages as intercumulus droplets. This rock has pyrrhotite with iron contents between 64.9 and $65.5 \%$, pentlandite with nickel contents between 14.6 and $25.3 \%$, and chalcopyrite with copper contents between 29.1 and $31.5 \%$. The rocks intensely transformed by metamorphism, which do not preserve igneous texture, have pyrrhotite-pentlandite, pyrrhotite-pentlandite-chalcopyrite, and pyrrhotite-pentlandite-chalcopyrite-pyrite assemblages, all of which accompanied with varying amounts of rutile. These assemblages have pyrrhotite with iron contents between 59.1 and $62.1 \%$, pentlandite with nickel contents between 15 and $40 \%$, and chalcopyrite with copper contents between 32.9 and $36.6 \%$. The pentlandite-pyrite association, as well as venules composed of pyrite or chalcopyrite, constitute phases of replacement and remobilization of pre-existing sulfides. Based on mineralogy, texture and base metal content, the sulfide assemblages found in the rocks intensely transformed by metamorphism are similar in both complexes and they differ from the sulfide assemblages found in the igneous textured rock. Therefore, it is suggested that the tectono-metamorphic processes related to the Brasiliano Cycle triggered remobilizations and chemical changes in the Ni-Cu sulfide ores from the Mangabal I and Mangabal II complexes.
\end{abstract}

Keywords: Mafic-ultramafic complexes; Brasiliano Cycle; Brasília Belt; Ni and Cu sulfide; Ore remobilization; Rutile. 


\section{INTRODUÇÃO}

Os complexos máfico-ultramáficos estratiformes Mangabal I e Mangabal II compõem um conjunto de intrusões sin-orogênicas dos estágios finais da orogenia Brasiliana/PanAfricana neoproterozoica (Pimentel et al., 2000; Laux et al., 2004). Essas intrusões são importantes por exibir potencial em hospedar minério sulfetado de Ni-Cu-EGP de filiação magmática e, portanto, de gênese atrelada a processos de saturação em enxofre, segregação, transporte e precipitação de sulfetos no decorrer de sua cristalização (Lightfoot et al., 2017; Naldrett, 2004). Muitos desses complexos na região central do Brasil não têm sido devidamente estudados, principalmente se considerados seu potencial metalogenético e minérios existentes. Como exceção, pode-se citar o complexo de Americano do Brasil, cujos aspectos texturais, mineralógicos e químicos sugerem mineralização de filiação magmática (Nilson, 1981; Mota-e-Silva, 2009; Mota-e-Silva et al., 2011). No caso dos complexos Mangabal I e Mangabal II, as associações mineralógicas em conjunto aos atributos texturais e químicos dos sulfetos têm indicado possível origem ígnea para o minério de ambos os complexos (Candia, 1983). No entanto, Candia (1983) ressalta que muitas das feições originais do minério provavelmente foram obliteradas por processos tectono-metamórficos.

Nesse contexto, este trabalho apresenta novos dados petrográficos e de microscopia eletrônica de varredura (MEV) referentes às zonas sulfetadas de Mangabal I e Mangabal II. Os objetivos principais foram reconhecer e caracterizar as diferentes associações de sulfetos com foco em seus aspectos genéticos e cronologia relativa.

\section{CONTEXTO GEOTECTÔNICO}

A Faixa de Dobramento Brasília compreende o domínio leste da Província Geotectônica Tocantins, que se desenvolveu durante a convergência entre os Crátons Amazônico e São Francisco, no decorrer do Ciclo Brasiliano/Pan-Africano, no Neoproterozoico (Almeida et al., 1981; Valeriano et al., 2004) (Figura 1A).

A Faixa Brasília é compartimentada em quatro principais terrenos geotectônicos (Figura 1B), que incluem:

- cinturão de dobramentos e empurrões composto de sequências metassedimentares depositadas na borda oeste do paleocontinente São Francisco;

- o complexo Anápolis-Itauçu, representado por ortogranulitos e paragranulitos do núcleo metamórfico exposto da Faixa Brasília;

- o Arco Magmático de Goiás, essencialmente formado por sequências metavulcanossedimentares e ortognaisses típicos de arcos juvenis, separado em suas porções setentrional e meridional, nos arcos de Mara Rosa e de
Arenópolis (AMA), respectivamente (Brito Neves et al., 2014; Pimentel et al., 2000);

- o maciço de Goiás, principalmente composto de ortognaisses tonalito-trondhjemito-granodiorito (TTG), terrenos greenstone belts e sequências metavulcanossedimentares arqueanas a mesoproterozoicas (Piuzana et al., 2003a).

Os complexos Mangabal I e Mangabal II fazem parte de um conjunto de intrusões máfico-ultramáficas sin-orogênicas, alojadas tanto no Complexo Anápolis-Itauçu quanto no AMA (Figura 1C). Essas intrusões são contemporâneas ao segundo evento magmático do Arco e datam entre 670 e $600 \mathrm{Ma}$ (Gioia, 1997; Pimentel et al., 2000; Laux et al., 2004; Della Giustina et al., 2011). Dados petrológicos e geoquímicos indicam que muitas dessas intrusões teriam se originado de um mesmo magma parental (Laux et al., 2004, 2005; Mota-e-Silva et al., 2011).

\section{Geologia local}

Os complexos máfico-ultramáficos Mangabal I e Mangabal II localizam-se a aproximadamente $140 \mathrm{~km}$ a noroeste da cidade de Goiânia, Goiás. Essas intrusões possuem formas semielípticas, dimensões relativamente pequenas $\left(<50 \mathrm{~km}^{2}\right)$ e alojam-se em muscovita-quartzo xisto da sequência Anicuns-Itaberaí e em gnaisses granodioríticos (Silva, 2012) pertencentes ao AMA (Figura 1C). Foliação metamórfica de direção NE-SW é bem desenvolvida nas unidades do AMA e principalmente nas bordas dos complexos, indicativas de contatos tectônicos entre as rochas dos complexos com as suas encaixantes.

Regionalmente, a sequência Anicuns-Itaberaí é ainda composta de pelitos, cherts, formações ferríferas, margas e rochas ultramáficas (Laux et al., 2004; Mota-e-Silva et al., 2011). Nas bordas e em alguns locais no interior dos complexos, ainda ocorrem lentes e enclaves de rochas calciossilicáticas e formações ferríferas (Candia, 1983; Silva, 2012).

Candia (1983), com base em dados geofísicos e petrográficos, postula que Mangabal I e Mangabal II constituem câmaras magmáticas com evoluções distintas. Segundo a autora, Mangabal I é principalmente composto de gabronorito (cumulatos de piroxênio e plagioclásio), olivina-gabronorito (cumulatos de olivina e plagioclásio) e peridotito (cumulatos de olivina e cromo-espinélio), enquanto em Mangabal II são reconhecidos peridotito com predomínio de ortopiroxênio (harzburgitos) e piroxenito (bronzitito), além de gabronorito e olivina-gabronorito semelhantes aos encontrados em Mangabal I. No conjunto, ambos os complexos foram afetados por processos tectono-metamórficos atribuídos ao Ciclo Brasiliano, que provocaram mudanças na estratigrafia original e recristalização metamórfica sobreposta às texturas e mineralogia ígneas reliquiares (Candia, 1983). 
O ápice metamórfico ao qual as rochas dos complexos foram submetidas é estimado em $700 \pm 50^{\circ} \mathrm{C}$ e $6-7 \mathrm{kbar}$, responsável pelo desenvolvimento de paragêneses compatíveis com fácies granulito ou com fácies anfibolito, a depender da razão fluido/rocha e da composição do fluido metamórfico (Candia, 1983; Candia et al., 1991).
B

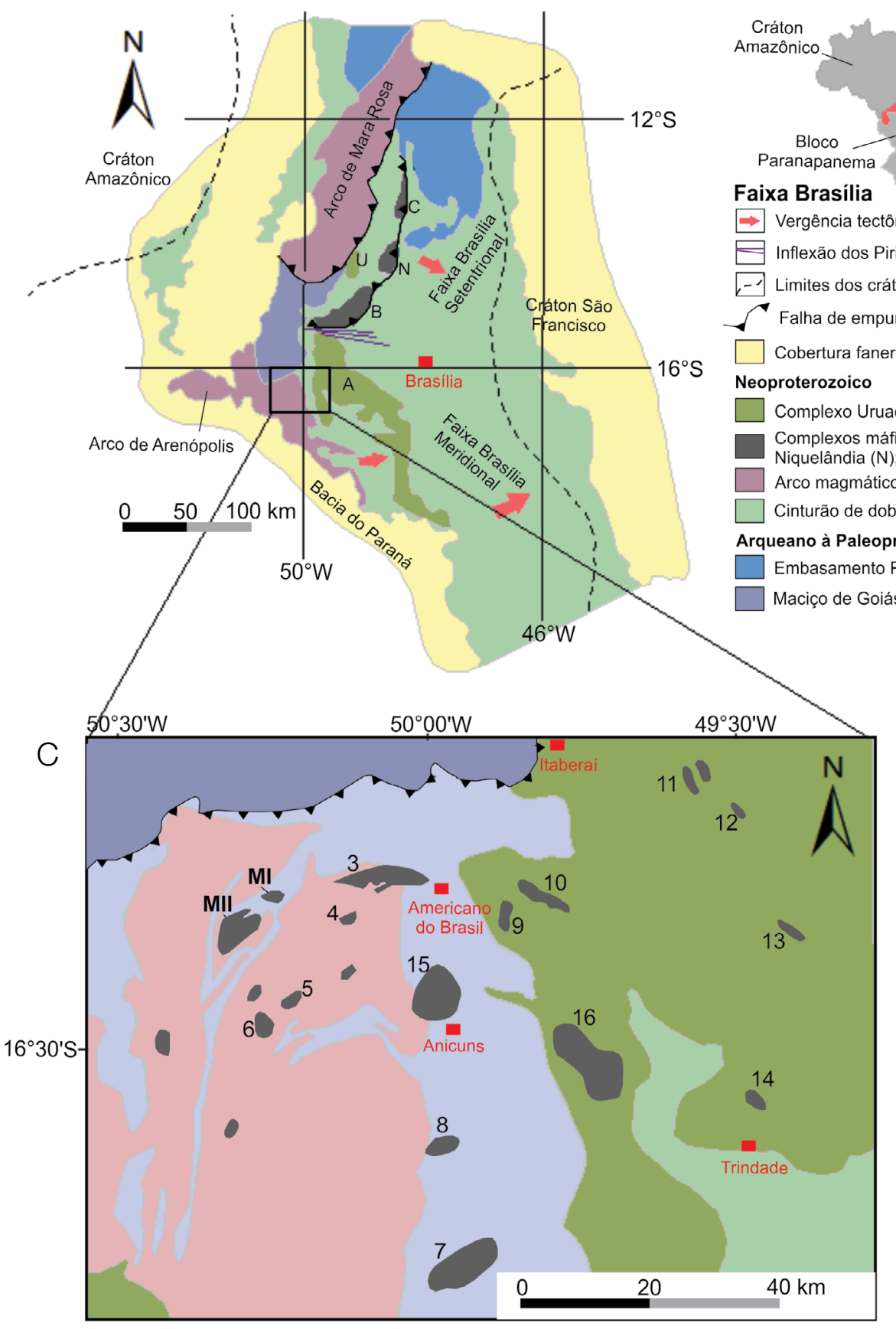

A

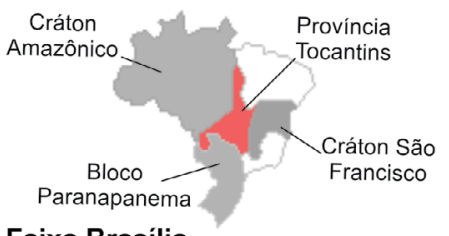

\section{Faixa Brasilia}

Cidade
Geologia da região de Anicuns

Cinturão de dobramentos e empurrões

Sequência de margem passiva Grupo Araxá (643 Ma)

Complexos máfico-ultramáficos $(600$ - $670 \mathrm{Ma})$

MI - Mangabal I, MII - Mangabal II, 3 - Americano do Brasil, 4 - Água Fria, 5 - Adelândia, 6 - Fronteira Norte, 7 - Palmeiras, 8 - Mata Rica e Palmito, 9 - Águas Claras, 10 - Capelinha,

11 - Taquaral, 12 - Santa Rosa,

13 - Damolândia, 14 - Goianira-Trindade). Intrusões gabro-dioríticas:

15 - Córrego Seco, 16 - Santa Bárbara

Arco Magmático de Arenópolis

Sequência vulcano-sedimentar

Anicuns-Itaberaí (840 - $805 \mathrm{Ma}$ )

Ortognaisses/granitóides juvenís (890 - $800 \mathrm{Ma}$ e 660 - $600 \mathrm{Ma}$ )

Complexo Anápolis-Itauçu

Paragranulitos/ortogranulitos (760 - $650 \mathrm{Ma}$ )

Maciço de Goiás

$\square$ Ortognaisses e greenstone belts (arqueano à paleoproterozoico)

Falha de empurrão

Cidade

Figura 1. (A) Localização da Província Geotectônica Tocantins; (B) compartimentação tectônica da Faixa Brasília (modificado de Della Giustina et al., 2011); (C) esboço geológico simplificado da região de Anicuns (modificado de Mota-e-Silva, 2011). As idades em parênteses representam deposição sedimentar ou cristalização ígnea. Para maiores informações quanto aos dados geocronológicos, os leitores podem se endereçar aos trabalhos de Piuzana et al. (2003a, 2003b), Della Giustina et al. (2011) e Mota-e-Silva et al. (2011). 
O reequilíbrio em fácies granulito produziu diferentes paragêneses, principalmente em função da atividade de sílica dos protólitos ígneos. O gabronorito gerou essencialmente plagioclásio, ortopiroxênio e/ou clinopiroxênio, enquanto o olivina-gabronorito gerou paragênese idêntica ao anterior, porém com adição de olivina, anfibólio pargasítico e espinélio (Candia e Girardi, 1991). Esses dois últimos, junto ao ortopiroxênio, constantemente formam coronas de reação no contato entre plagioclásio e olivina, observadas nos litotipos máficos e ultramáficos de ambos os complexos (Candia et al., 1991). O reequilíbrio em fácies anfibolito desenvolveu olivina, ortopiroxênio, hornblenda e clorita nos litotipos ultramáficos, enquanto formou plagioclásio (andesina), hornblenda, rutilo, ilmenita e ortoanfibólios nos litotipos máficos (Candia, 1983; Candia et al., 1991).

No que concerne ao minério dos complexos, Candia (1983) reconhece duas principais associações de sulfetos, que formam glóbulos intercumulus. A primeira é representada por pirrotita-pentlandita-calcopirita, presente em ambos os complexos. A segunda é constituída de pirrotita-calcopirita-pentlandita-pirita, com predomínio de pirrotita e calcopirita nos litotipos máficos e de pirrotita e pentlandita nos tipos ultramáficos, sendo essa associação reconhecível, segundo a autora, somente em Mangabal II. Posteriormente, Silva (2012) reconhece em Mangabal I a associação pirrotita-pentlandita-calcopirita hospedada em peridotito, enquanto a associação pirrotita-pentlandita-calcopirita-pirita, hospedada em metagabronorito e metapiroxenito, é reconhecida em ambos os complexos. Nesses últimos, quantidade expressiva de rutilo acompanha as associações de sulfetos (Silva, 2012). Recentemente, Augustin e Della Giustina (2019) reconhecem as associações pirrotita-pentlandita-calcopirita-pirita e pirita-milerita e sugerem que estas são mais enriquecidas em níquel, cobre e EGP quando associadas a litotipos metamórficos e a zonas de cisalhamento.

\section{MATERIAIS E MÉTODOS}

Os estudos petrográficos e por MEV foram desenvolvidos a partir de quatro amostras ao longo de um testemunho de sondagem de Mangabal I (SAN0095) e três amostras provenientes de um testemunho de sondagem de Mangabal II (SAN0038). Os litotipos foram fotografados com câmera Canon modelo DS126201 acoplada ao microscópio Zeiss modelo Axioskop 40. As associações de sulfetos também foram imageadas por elétrons-retroespalhados (BSE) e analisadas por detector de energia dispersiva (EDS) junto a um microscópio eletrônico de varredura da marca JEOL, modelo JSM-6010 LA, operado com tensão de aceleração de $15 \mathrm{kV}$ e distância focal de $10 \mathrm{~mm}$. Todas as etapas foram desenvolvidas junto ao Departamento de Petrologia e Metalogenia do Instituto de Geociências e
Ciências Exatas da Universidade Estadual Paulista "Júlio de Mesquita Filho" (UNESP)/Rio Claro, São Paulo.

A classificação dos litotipos baseia-se em Streckeisen (1976). Para simplificação, quando o litotipo preserva a textura cumulática (ígnea) do protólito, mesmo considerando-se reequilíbrios metamórficos associados à formação de textura coronítica, o adjetivo "meta" é abstraído de sua classificação, com referenciação no texto como litotipo de textura ígnea. Quando o litotipo não preserva a textura ígnea original e encontra-se intensamente metamorfizado, o adjetivo "meta" é acrescentado à classificação. Junto ao nome de cada litotipo também é adicionado o "I" ou o "II", referente à proveniência do complexo ao qual pertencem: Mangabal I ou Mangabal II, respectivamente. Em adicional, os percentuais minerais foram calculados após contagem modal por pontos.

Os sulfetos são agrupados em associações de sulfetos (A1, A2 etc.) quando ocorrem em conjunto com aparente equilíbrio. O termo paragênese não é usado em razão da possibilidade de os sulfetos constituintes das associações não serem cogenéticos. As siglas das associações de sulfetos em litotipos intensamente metamorfisados estão acompanhadas da letra "m" sobrescrita, enquanto nas siglas das associações de sulfetos em litotipos de textura ígnea, não há acréscimo de pós-fixo.

Nas pranchas fotográficas são utilizadas as siglas de minerais propostas por Whitney e Evans (2010).

\section{RESULTADOS}

\section{Petrografia dos litotipos de Mangabal I}

Na região do testemunho SAN0095, as rochas apresentam foliação metamórfica NE-SW associada à paragênese de fácies anfibolito (Silva, 2012, Figura 2).

\section{Lherzolito' (195,92 m)}

A rocha possui granulometria fina $(<0,2 \mathrm{~mm})$ e textura cumulática preservada, conferida por cristais subédricos de olivina (60\%) e cristais subédricos a euédricos de espinélio amarronzado (cromoespinélio) (1\%). Cristais de ortopiroxênio (7\%), clinopiroxênio (10\%), anfibólio acastanhado (hornblenda, 4\%) e plagioclásio (7\%) formam oikocrysts que, juntamente com raros cristais de flogopita/biotita (traço), constituem a fase intercumulus. Em adicional, coronas de reação em cristais de olivina encontram-se desenvolvidas e constituídas de ortopiroxênio em suas faixas internas e por anfibólio (4\%) e espinélio (1\%) esverdeados em suas faixas externas.

A fase sulfetada (4\%) é constituída de pirrotita-pentlandita (A1) e pirrotita-pentlandita-calcopirita (A2), que ocorrem na forma de glóbulos e gotas de sulfetos intercumulus 
(Figuras 3A e 3B), ou preenchendo fraturas em cristais de olivina. Os óxidos associados à $\mathrm{A} 1$ e $\mathrm{A} 2$ são representados por cristais subédricos a euédricos de ilmenita (1\%) e magnetita (1\%).

Em algumas porções, as imagens BSE mostram finas faixas de pentlandita e calcopirita alternadas (Figura 3C), sugestivas de exsolução ou substituição entre essas fases minerais. Também se observou pequena concentração de bornita confinada a fraturas ou planos de fraqueza interna e/ou em substituição de cristais de pentlandita e pirrotita, principalmente em suas bordas (Figura 3D).

\section{Meta-olivina-ortopiroxenito' $(168,03 \mathrm{~m})$}

Exibe granulometria média a grossa $(0,2-10 \mathrm{~mm})$, textura cumulática reliquiar pouco preservada e definida por cristais de olivina $(20 \%)$ da fase cumulus e ortopiroxênio $(17 \%)$, possivelmente da fase intercumulus. Textura predominantemente metamórfica é evidenciada por coronas de reação em cristais de olivina e por anfibólio (grupo da cummingtonita, $40 \%$ ) anédrico a subédrico, flogopita (10\%) e clorita (1\%), em textura nematoblástica a lepidoblástica.

O anfibólio anédrico é caracterizado pelo aspecto turvo em razão da grande quantidade de inclusões/exsoluções microcristalinas de magnetita e ilmenita (4\%), enquanto o subédrico, oriundo de recristalização posterior, é geralmente límpido e com poucas inclusões.

Os sulfetos (8\%) são representados por pirrotita-pentlandita-calcopirita $\left(\mathrm{A} 2^{\mathrm{m}}\right)$ na forma de agregados subparalelos aos cristais de anfibólio (Figuras 4A a 4C) e de flogopita orientados. A pentlandita ocorre tanto na forma de cristais quanto na de exsoluções lamelares na pirrotita (Figura 4C). Nota-se que nas porções nematoblásticas e lepidoblásticas, a associação $\mathrm{A} 2^{\mathrm{m}}$ apresenta maiores proporções de calcopirita em relação aos demais sulfetos (Figura 4B).

Calcopirita também ocorre na forma de vênulas que se prolongam da associação $\mathrm{A} 2^{\mathrm{m}}$ e preenchem planos de fratura na rocha. Cristais subédricos a euédricos de magnetita e ilmenita estão em aparente equilíbrio tanto no centro quanto nas bordas da $\mathrm{A} 2^{\mathrm{m}}$, enquanto esses óxidos são seccionados pelas vênulas de calcopirita (Figura 4D).

\section{Metagabro' (152,52 m)}

Rocha de granulometria média a grossa $(0,2-10 \mathrm{~mm})$ com domínios de textura granoblástica poligonal à denteada, definidas por cristais de plagioclásio (30\%), e domínios de textura granoblástica decussada conferida por cristais de hornblenda (52\%). De modo pontual, cristais de hornblenda encontram-se orientados e definem setores nematoblásticos.

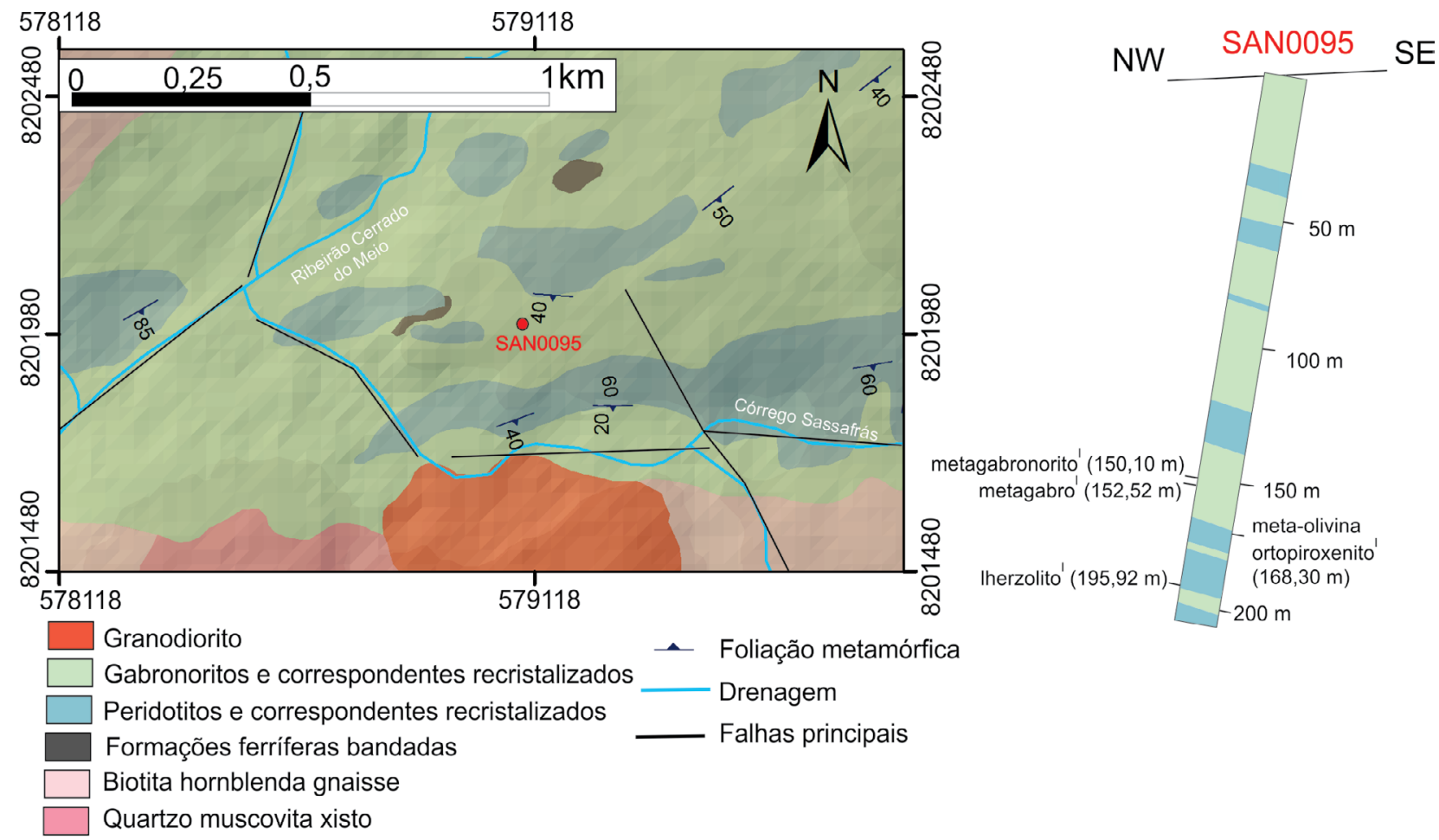

Fonte: adaptado de Silva (2012).

Figura 2. Mapa geológico simplificado da porção oeste de Mangabal I com a localização das amostras coletadas. 
Resquícios de textura cumulática são sugeridos pela presença de pseudomorfos de clinopiroxênio, completamente substituídos por agregados de cristais de hornblenda.

A hornblenda, em geral, apresenta inclusões/exsoluções criptocristalinas de minerais opacos (7\%) e inclusões microcristalinas de titanita $(3 \%)$ e rutilo $(1 \%)$. No centro dos pseudomorfos, intercrescimentos simplectíticos entre quartzo (2\%) e hornblenda (Figura 5A) são comuns. O plagioclásio apresenta-se levemente saussuritizado, com carbonatos $(3 \%)$ e epídoto $(1 \%)$, tanto em seu interior quanto em suas bordas. Biotita (1\%) e apatita (traço) ocorrem como fases acessórias.

Os sulfetos (5\%) são representados por pirrotita-pentlandita-calcopirita $\left(\mathrm{A} 2^{\mathrm{m}}\right)$ e pirrotita-pentlandita-calcopirita-pirita $\left(\mathrm{A} 3^{\mathrm{m}}\right)$, intersticiais aos cristais de hornblenda (Figura 5B). A pentlandita é tipicamente granular, ao passo que a calcopirita forma faixas irregulares que envolvem cristais euédricos de pirita (Figura 5C). $\mathrm{A} 2^{\mathrm{m}}$ e $\mathrm{A} 3^{\mathrm{m}}$ encontram-se parcialmente substituídas por pentlandita-pirita $\left(\mathrm{A} 4^{\mathrm{m}}\right)$, que configura intercrescimentos vermiculares (Figura 5D). Os cristais de rutilo ocorrem em aparente equilíbrio com $\mathrm{A} 2^{\mathrm{m}} \mathrm{e} \mathrm{A} 3^{\mathrm{m}}$, principalmente nas bordas dos sulfetos (Figura 5B).

\section{Metagabronorito' $(150,10 \mathrm{~m})$}

Apresenta granulometria fina $(<0,2 \mathrm{~mm})$, domínios com textura granoblástica poligonal definida por plagioclásio (36\%), domínios com textura granoblástica decussada representada por anfibólio (40\%) sem orientação preferencial, e domínios de textura nematoblástica conferida por anfibólio orientado.

Localmente, pequeno setor de brecha sulfetada $(\sim 1 \mathrm{~cm})$ é composto de matriz de minerais opacos e clastos da rocha encaixante, constituídos de agregados de cristais de anfibólio (Figura 6A). Os anfibólios são representados por clinoanfibólio incolor a levemente esverdeado e pleocroico (grupo da cummingtonita), além de clinoanfibólio esverdeado e
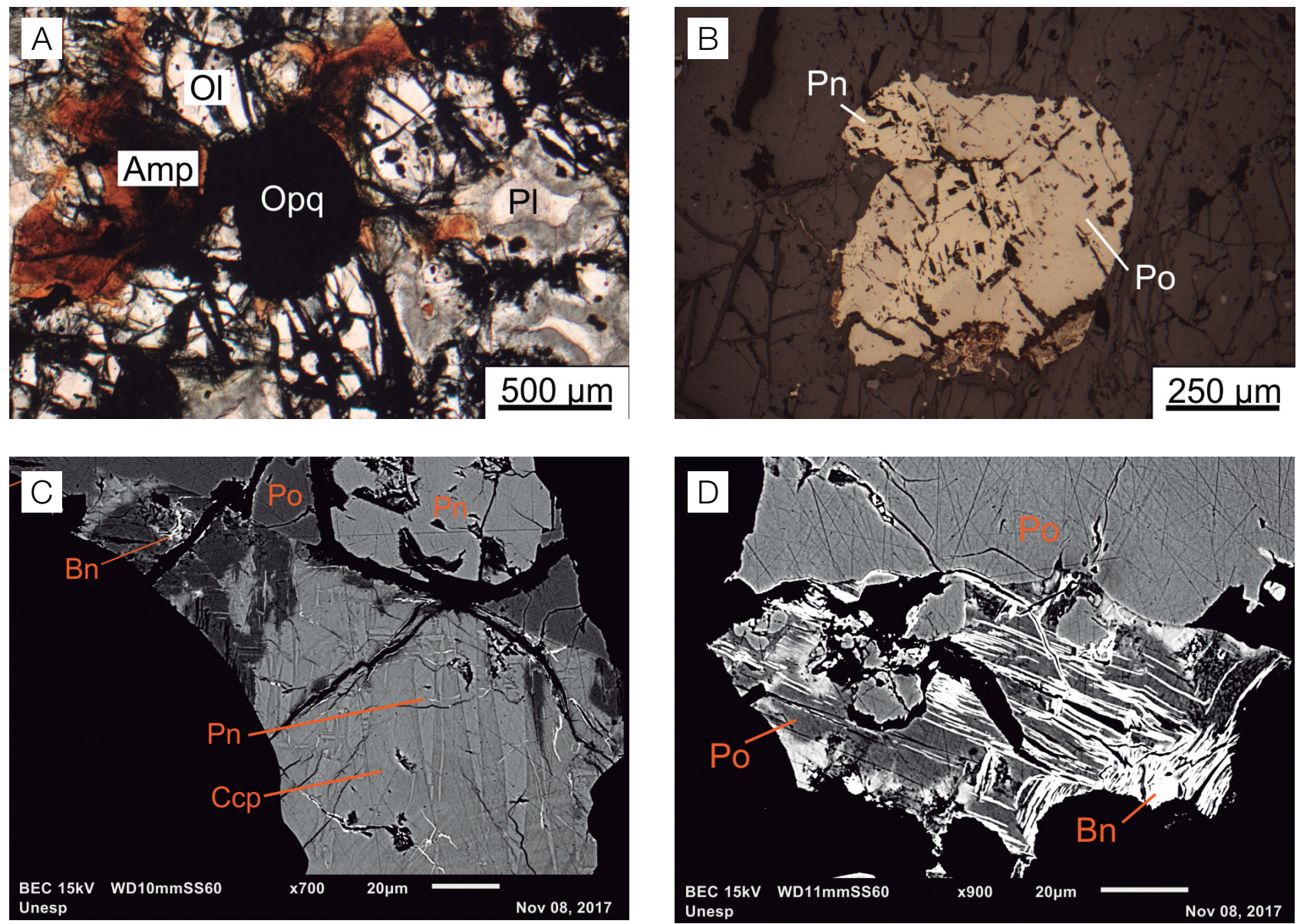

Ol: olivina; Amp: anfibólio; Opq: opacos; PI: plagioclásio; Pn: pentlandita; Po: pirrotita; Bn: bornita; Ccp: calcopirita.

Figura 3. Fotomicrografias do Iherzolito: (A) glóbulo de sulfeto intercumulus; (B) glóbulo anterior composto de pirrotitapentlandita (A1); (C) alternância entre faixas de pentlandita e calcopirita (imagem BSE); (D) substituição de bornita em pirrotita (imagem BSE). 
pleocroico (grupo da hornblenda), indicativos de protólito com ortopiroxênio e clinopiroxênio. Os anfibólios comumente apresentam inclusões/exsoluções microcristalinas de rutilo, magnetita e ilmenita (5\%), e formam intercrescimentos com quartzo (2\%). A rocha ainda apresenta flogopita/biotita ( $1 \%$ ), carbonato (1\%) e apatita (traço) como fases subordinadas.

Os sulfetos (15\%) são representados por pirrotita-pentlandita-calcopirita-pirita $\left(\mathrm{A}^{\mathrm{m}}\right)$ na forma de agregados subparalelos à orientação dos anfibólios. Essa associação ocorre em estilo disseminado ou como matriz da brecha descrita anteriormente (Figuras 6A e 6B). A calcopirita forma faixas ao redor de cristais euédricos de pirita (Figura 6B), enquanto rutilo aparece principalmente nas bordas dos sulfetos.

A pirita também constitui vênulas que preenchem planos de fratura na rocha, as quais seccionam sulfetos da $\mathrm{A} 3^{\mathrm{m}} \mathrm{e}$ cristais de rutilo, embora supostamente não seccionem cristais de flogopita/biotita (Figuras 6C a 6F).

\section{Análise composicional dos sulfetos de Mangabal I}

As associações A1 e A2 encontradas no lherzolito ${ }^{\mathrm{I}}$, que preserva a textura cumulática do protólito, são caracterizadas por pirrotita com conteúdos de ferro entre 64,9 e $65,5 \%$, além de pentlandita com conteúdos de níquel entre 24,3 e $25,5 \%$. Um único cristal forneceu valor anômalo de $14,6 \%$ de níquel, possivelmente derivado de análise mista entre pentlandita e pirrotita. Ainda no lherzolito ${ }^{\mathrm{I}}$, a calcopirita da A2 possui conteúdos de cobre entre 29,1 e $31,5 \%$, enquanto a bornita, que representa uma fase de substituição ou preenche fraturas em A1 e A2, apresenta conteúdos de cobre entre 51,9 e $67,3 \%$.

As associações $\mathrm{A} 2^{\mathrm{m}}$ e $\mathrm{A} 3^{\mathrm{m}}$ encontradas no metagabro ${ }^{\mathrm{I}}$ e metagabronorito ${ }^{\mathrm{I}}$, ambos intensamente metamorfisados, apresentam pirrotita com conteúdos em ferro entre 59,1 e $62 \%$; pentlandita com conteúdos de níquel de 36,7 a $39,4 \%$, e calcopirita com conteúdos de cobre entre 32,9 e
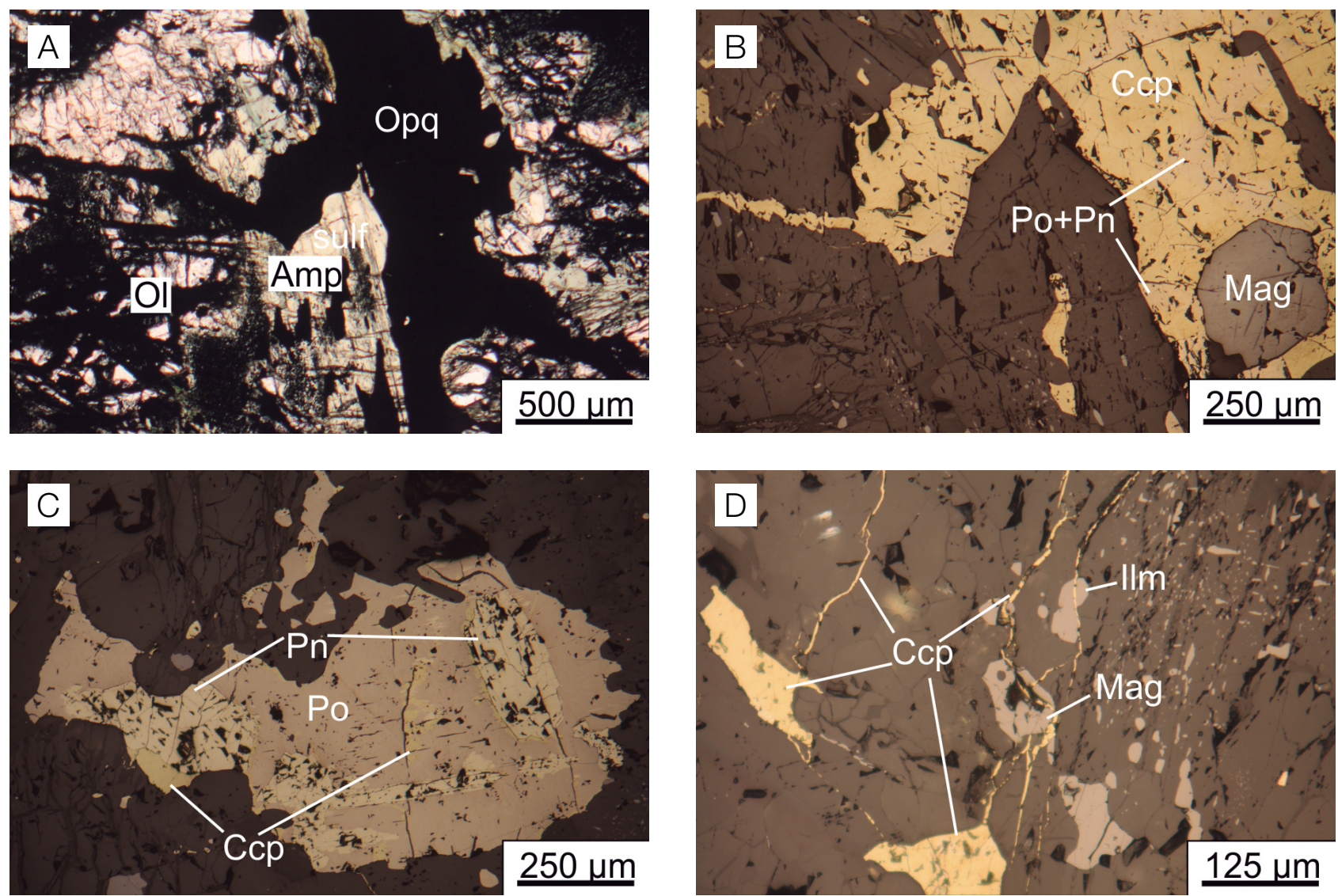

Opq: opacos; Ol: olivina; Amp: anfibólio; Po: pirrotita; Pn: pentlandita; Mag: magnetita; Ccp: calcopirita; IIm: ilmenita.

Figura 4. Fotomicrografias do meta-olivina-ortopiroxenito': (A) concentração de minerais opacos intersticiais aos cristais de anfibólio (grupo da cummingtonita) e olivina; (B) concentração anterior composta da associação pirrotita-pentlanditacalcopirita $\left(\mathrm{A} 2^{\mathrm{m}}\right)$ com predomínio de calcopirita; $(\mathrm{C})$ associação pirrotita-pentlandita-calcopirita $\left(\mathrm{A} 2^{\mathrm{m}}\right)$ com predomínio de pirrotita e pentlandita granular; (D) calcopirita venular e seccionando cristais de magnetita e ilmenita. 
$36,6 \%$. A pirita da $\mathrm{A} 3^{\mathrm{m}}$ apresenta conteúdos de ferro entre 45,6 e $50,8 \%$.

A associação $\mathrm{A} 4^{\mathrm{m}}$ reconhecida no metagabro $\mathrm{I}$ e no metagabronorito que substitui a $\mathrm{A} 2^{\mathrm{m}}$ e a $\mathrm{A} 3^{\mathrm{m}}$ apresenta pentlandita com conteúdos de níquel de $25 \%$ e pirita com valores de ferro entre 46,1 e $48,8 \%$. A pirita proveniente das vênulas no metagabro $\mathrm{I}$ e no metagabronorito ${ }^{\mathrm{I}}$ apresenta conteúdos de ferro de $46 \%$.

A pentlandita da $\mathrm{A} 1^{\mathrm{m}}$ e da $\mathrm{A} 2^{\mathrm{m}}$ mostra correlação negativa entre os conteúdos de níquel e enxofre (Figura 7A). Entretanto, a pentlandita da $\mathrm{A} 1$ e da $\mathrm{A} 2$ não apresenta correlação nítida entre os conteúdos de níquel e enxofre, as quais também não acompanham a correlação anterior (Figura 7A). A pentlandita da $\mathrm{A} 4^{\mathrm{m}}$ exibe conteúdos de níquel e enxofre que encontram-se aparentemente no prolongamento da tendência observada para as pentlanditas da $\mathrm{A} 1^{\mathrm{m}} \mathrm{e} \mathrm{A} 2^{\mathrm{m}}$ (Figura $7 \mathrm{~A}$ ), o que reforça a hipótese de que $\mathrm{A} 4^{\mathrm{m}}$ seria derivada da $\mathrm{A} 1^{\mathrm{m}}$ e da $\mathrm{A} 2^{\mathrm{m}}$.

A calcopirita da $\mathrm{A} 2^{\mathrm{m}}$ e da $\mathrm{A} 3^{\mathrm{m}}$ também mostra correlação negativa entre os conteúdos de cobre e enxofre (Figura 7B), enquanto a calcopirita da $\mathrm{A} 2$ mostra fraca correlação positiva entre os tores de cobre e enxofre (Figura 7B), distinto, portanto, do padrão observado para a calcopirita da $\mathrm{A} 2^{\mathrm{m}} \mathrm{e}$ da $\mathrm{A}^{\mathrm{m}}$.

\section{Petrografia dos litotipos de Mangabal II}

O testemunho SAN0038 localiza-se na porção sudeste de Mangabal II, onde ocorrem principalmente metaperidotitos e metagabronoritos apresentando foliação metamórfica NE-SW, concordante à foliação do biotita-hornblenda gnaisse encaixante (Silva, 2012, Figura 8).

\section{Metagabronorito" $(158,30 \mathrm{~m})$}

Exibe granulometria média a grossa $(0,2-10 \mathrm{~mm})$ com domínios de textura nematoblástica à granoblástica decussada definidos por cristais subédricos de anfibólio (55\%), intercalados a domínios granoblásticos poligonais conferidos por cristais
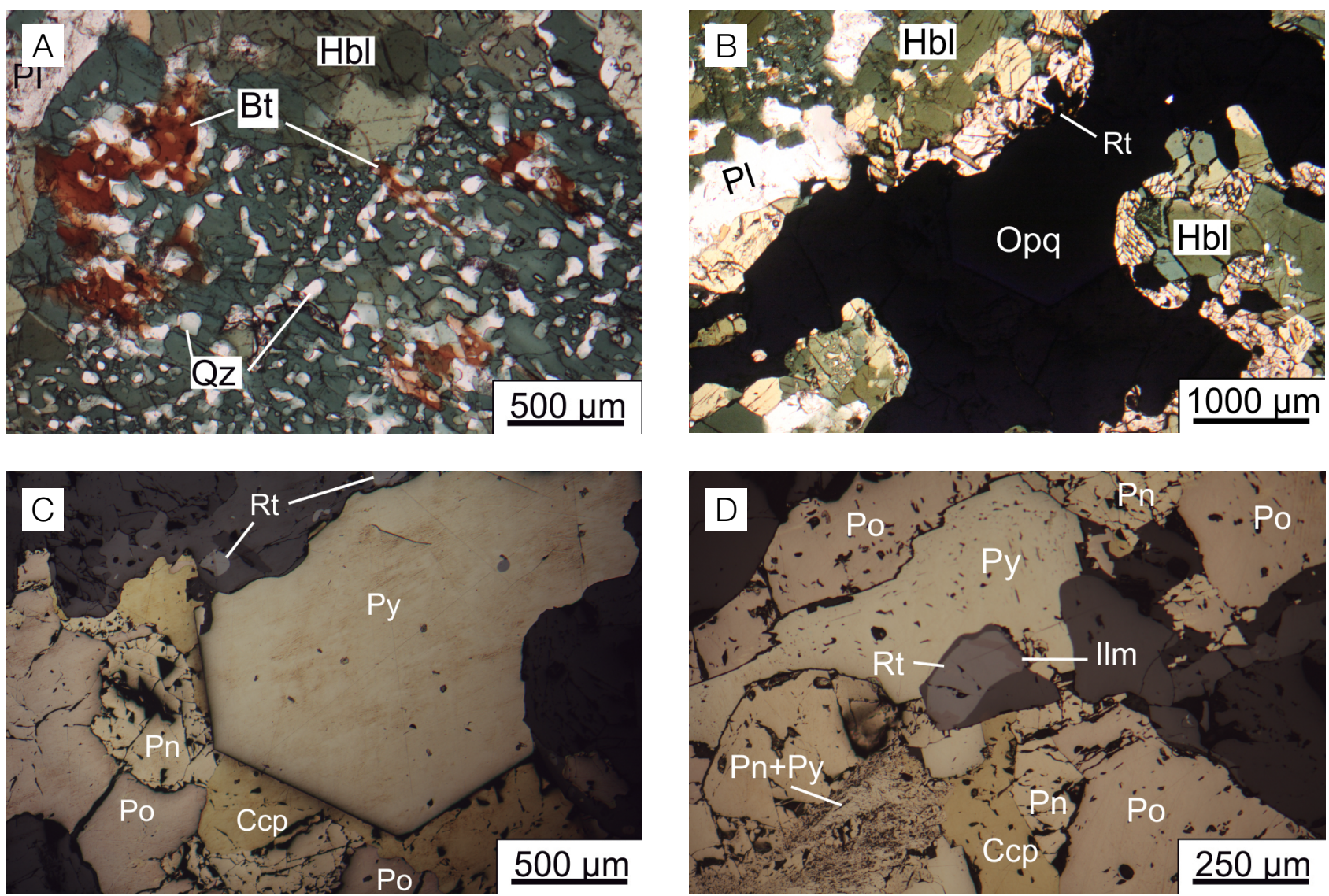

PI: plagioclásio; Bt: biotita; Hbl: hornblenda; Qz: quartzo; Rt: rutilo; Opq: opacos; Py: pirita; Pn: pentlandita; Po: pirrotita; Ccp: calcopirita; IIm: ilmenita.

Figura 5. Fotomicrografias do metagabro: (A) textura simplectítica entre quartzo e hornblenda; (B) concentração de minerais opacos intersticial aos cristais de hornblenda; (C) concentração anterior constituída de pirrotita-pentlanditacalcopirita-pirita $\left(A 3^{m}\right)$ com alguns cristais de rutilo; (D) associação $A 3^{m}$ parcialmente substituída pela associação pentlandita-pirita $\left(A 4^{m}\right)$ (porção inferior esquerda da imagem). 
anédricos a subédricos de plagioclásio (30\%). Textura ígnea reliquiar é sugerida pelo reconhecimento de pseudomorfos de clinopiroxênio e ortopiroxênio, possivelmente da fase cumulus reliquiar definida por agregados de anfibólio esverdeado e pleocroico (grupos da pargasita e da edenita) e de anfibólio incolor (grupos da cummingtonita e da antofilita).
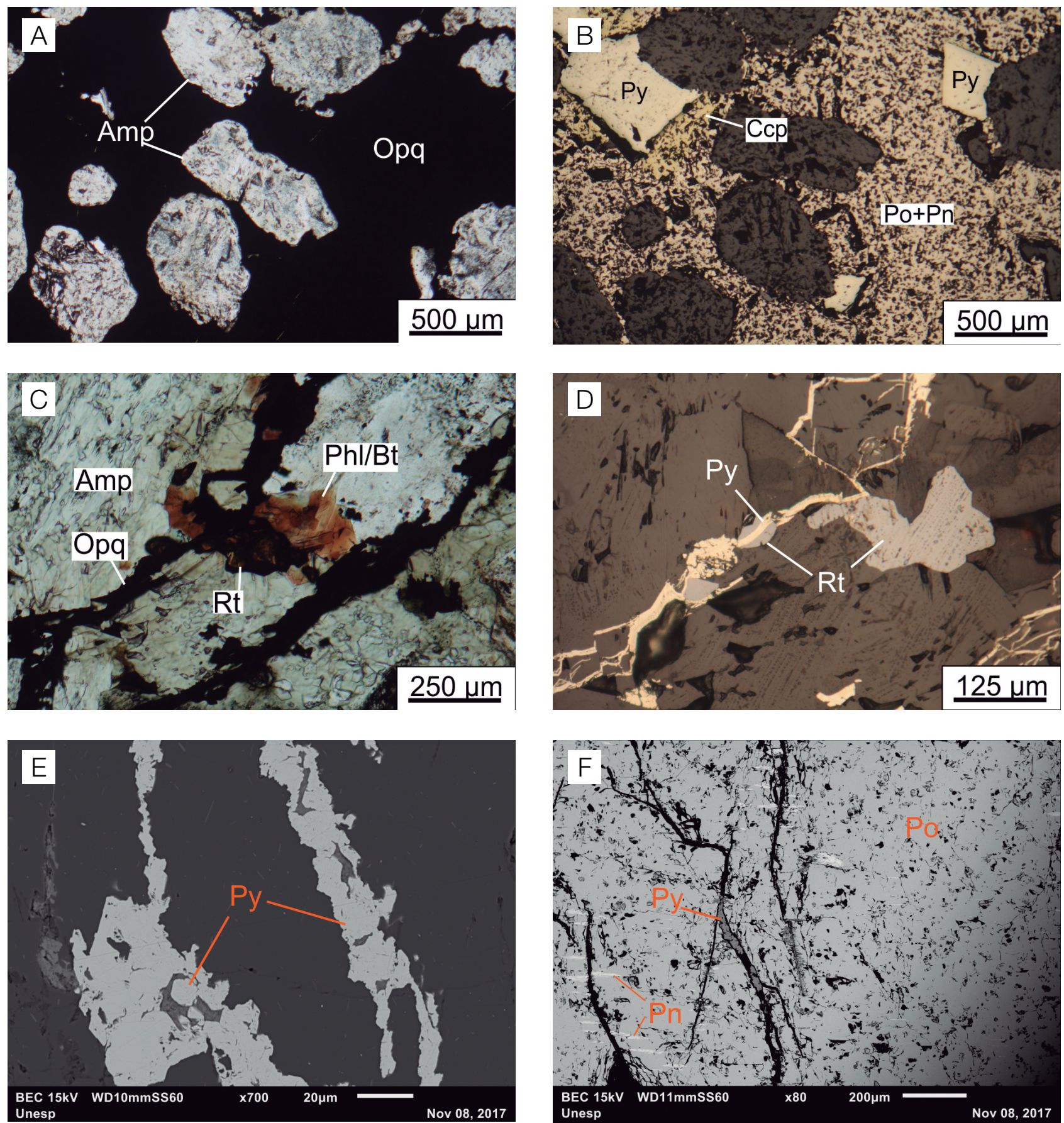

Amp: anfibólio; Opq: opacos; Py: pirita; Ccp: calcopirita; Po: pirrotita; Pn: pentlandita; Phl: flogopita; Bt: biotita; Rt: rutilo.

Figura 6. Fotomicrografias do metagabronorito: (A) brecha composta de clastos da rocha metamórfica (agregados de anfibólios); (B) matriz da brecha constituída da associação pirrotita-pentlandita-calcopirita-pirita (A3m); (C) planos de fratura preenchidos por minerais opacos associados ao rutilo e à flogopita/biotita; (D) fraturas anteriores, preenchidas por pirita, que seccionam cristais de rutilo, mas não os de flogopita/biotita; planos de fratura preenchidos por (E) pirita (imagem BSE) e (F) pirita em cristal de pirrotita (imagem BSE). 
Alguns cristais de anfibólio possuem aspecto turvo em seu interior em razão da presença de inclusões/exsoluções microcristalinas de rutilo $(2 \%)$, que em conjunto à ilmenita (1\%), compõem inclusões criptocristalinas e aciculares no plagioclásio. Epídoto (1\%) e carbonatos (1\%) são reconhecidos nos interstícios dos cristais de plagioclásio. Adicionalmente, observa-se flogopita/biotita (1\%) associada ao anfibólio, quartzo (1\%) intercrescido ao plagioclásio em pequeno veio (material mobilizado), além de apatita como mineral traço.

A fase sulfetada (7\%) é representada pelas associações pirrotita-pentlandita-calcopirita $\left(\mathrm{A} 2^{\mathrm{m}}\right)$ e pirrotita-pentlandita-calcoprita-pirita $\left(\mathrm{A}^{\mathrm{m}}\right)$ na forma de agregados intersticiais entre os cristais de anfibólio (Figura 9A). Nota-se que $\mathrm{A} 2^{\mathrm{m}}$ e $\mathrm{A} 3^{\mathrm{m}}$ apresentam pirrotita ou calcopirita (Figura 9B) como sulfetos predominantes. Rutilo e, menos frequentemente, ilmenita estão associados aos sulfetos. Localmente, a associação pentlandita-pirita $\left(\mathrm{A} 4^{\mathrm{m}}\right)$ forma intercrescimentos vermiculares a partir da substituição da pentlandita da $\mathrm{A} 2^{\mathrm{m}}$ e da $\mathrm{A} 3^{\mathrm{m}}$. Pirita forma preenche vênulas que eventualmente seccionam a $\mathrm{A}^{\mathrm{m}} \mathrm{e} \mathrm{a} \mathrm{A} 3^{\mathrm{m}}$.

\section{Metawebsterito"l $(95,33 \mathrm{~m})$}

Apresenta granulometria grossa $(1-10 \mathrm{~mm})$, textura nematoblástica (Figura 10A) definida por cristais subédricos de

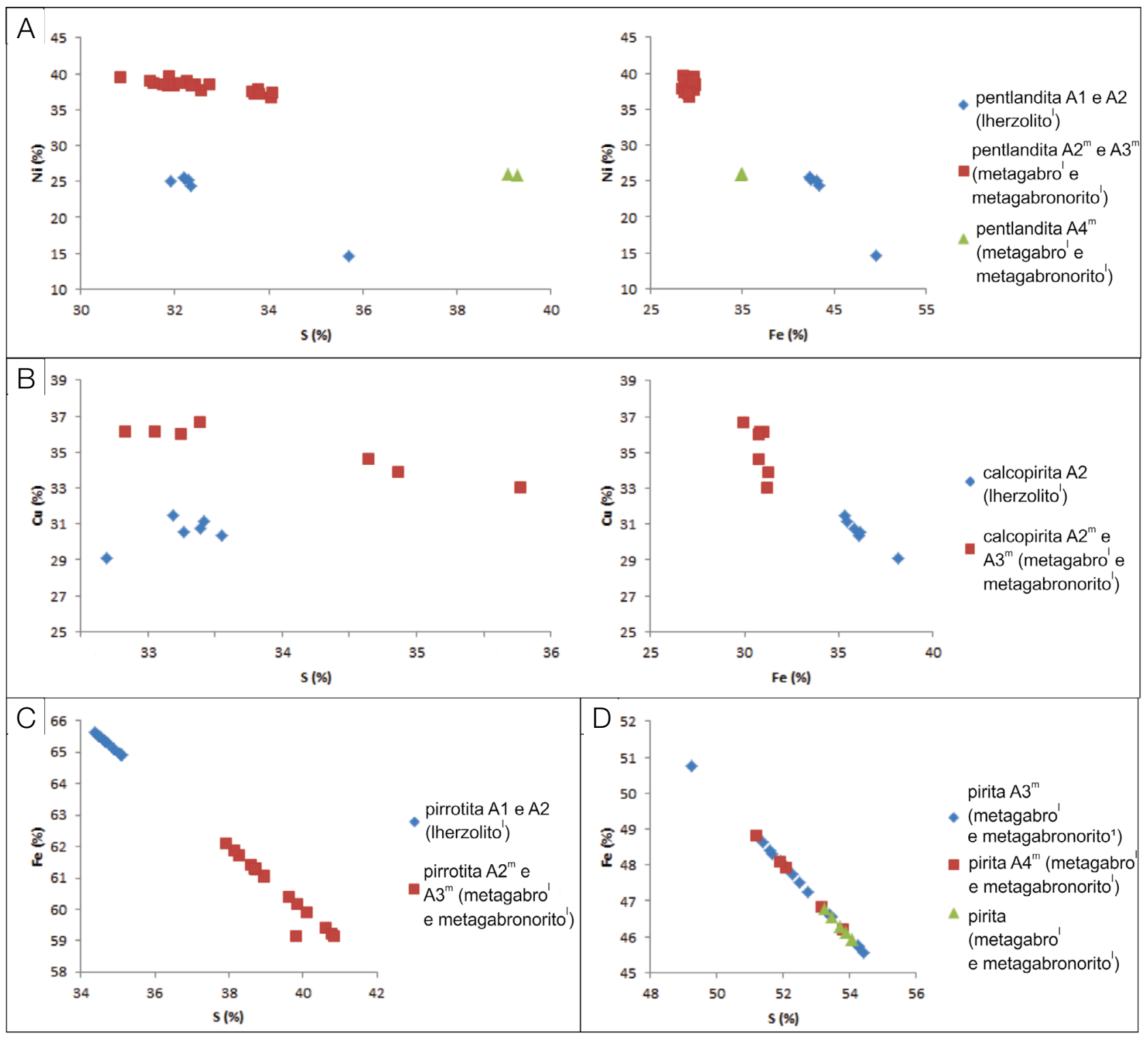

Figura 7. Diagramas binários de correlação linear entre os conteúdos de: níquel, ferro e enxofre na pentlandita; cobre, ferro e enxofre na calcopirita e; ferro e enxofre na pirrotita e na pirita, observados nas zonas sulfetadas de Mangabal I. 
antofilita (55\%), além de brecha composta de clastos de metawebsterito ${ }^{\mathrm{II}}$ envoltos por matriz constituída de plagioclásio (7\%), sulfetos $(23 \%)$ e rutilo ( $2 \%$ modal). Textura ígnea é sugerida por relictos de ortopiroxênio $(8 \%)$ restritos à textura nematoblástica e possivelmente da fase cumulus. O ortopiroxênio está parcialmente substituído por agregados de antofilita. No mais, cummingtonita e edenita/pargasita também estão presentes. $\mathrm{O}$ primeiro geralmente substitui a antofilita em porções de maior deformação (zonas de cisalhamento), enquanto a edenita/pargasita exibe inclusões/exsoluções de rutilo (Figura 10B) e ocorre dispersa na matriz, ou constitui cristais límpidos resultados de recristalização posterior.

A flogopita/biotita (3\%) é subédrica, exibe inclusões granulares de rutilo intercrescidas com, ou substituindo, a cummingtonita (Figuras 10A e 10B). O plagioclásio é anédrico à subédrico na porção da brecha ou preenche pequenas fraturas em associação a flogopita/biotita e carbonato (1\%). Ilmenita $(1 \%)$ e apatita (traço) ocorrem como fases acessórias.

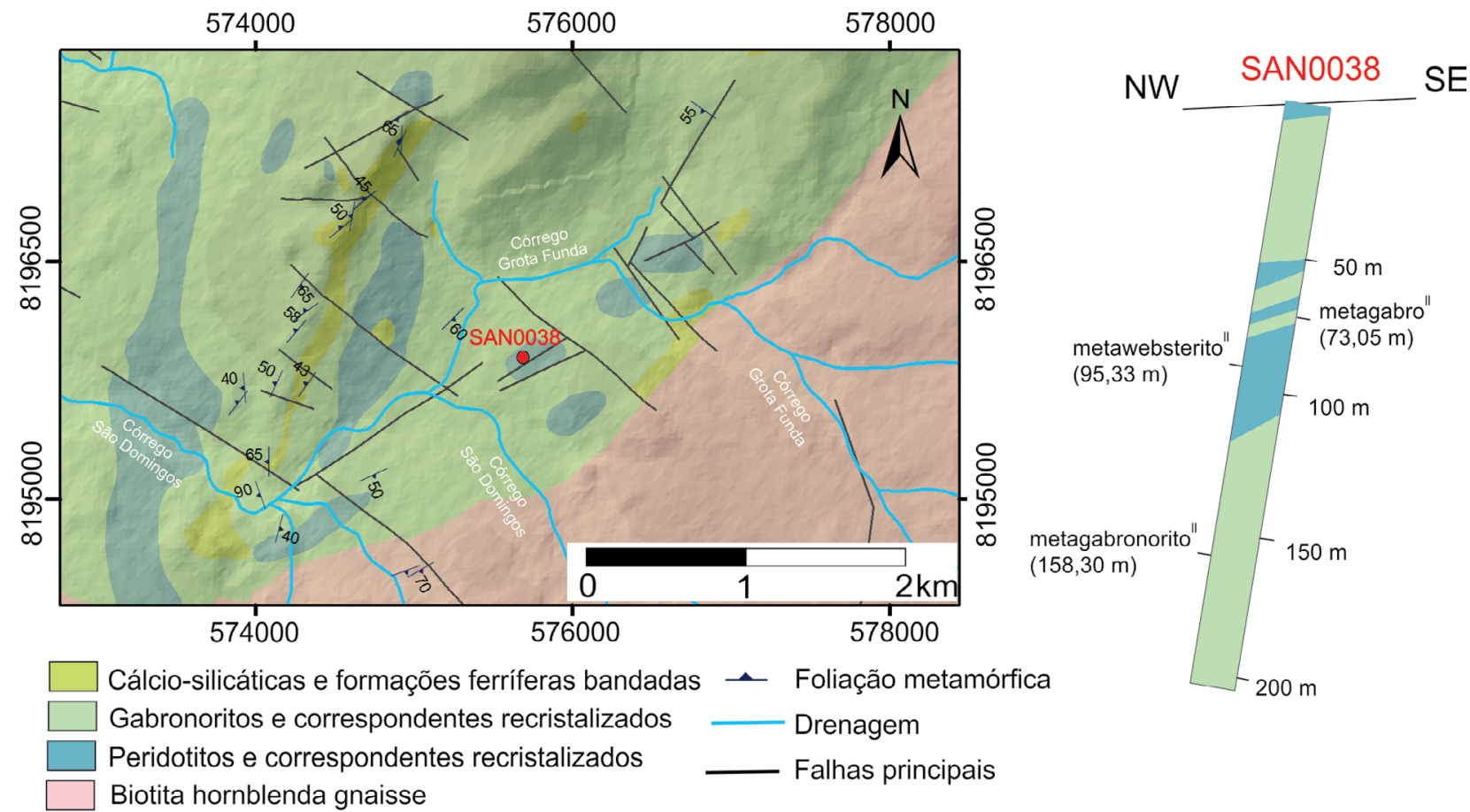

Fonte: adaptado de Silva (2012).

Figura 8. Mapa geológico simplificado da porção sudeste de Mangabal II com a localização das amostras coletadas.
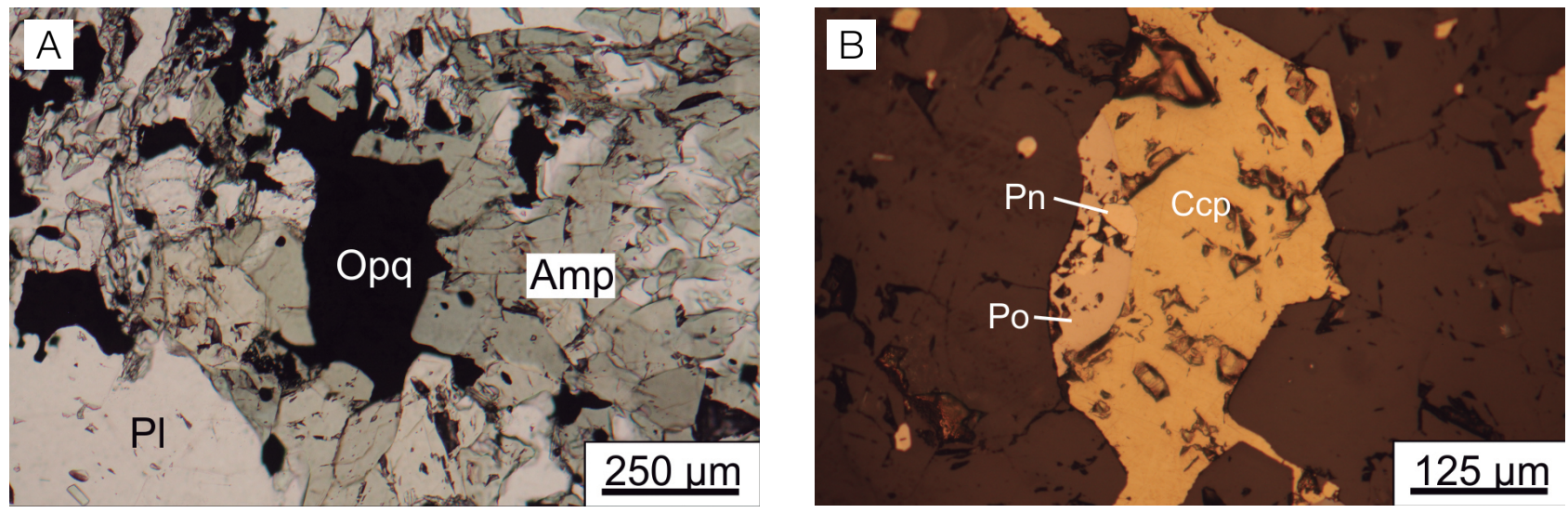

PI: plagioclásio; Opq: opacos; Amp: anfibólio; Pn: pentlandita; Po: pirrotita; Ccp: calcopirita.

Figura 9. Fotomicrografias do metagabronorito": (A) concentração de minerais opacos intersticial aos cristais de anfibólio; (B) concentração anterior composta de pirrotita-pentlandita-calcopirita $\left(A 2^{\mathrm{m}}\right)$ com predomínio de calcopirita. 
Os sulfetos são representados pelas associações pirrotita-pentlandita-calcopirita (A2 ${ }^{\mathrm{m}}$ ) (Figuras $10 \mathrm{C}$ a $10 \mathrm{E}$ ) e pirrotita-pentlandita-calcopirita-pirita $\left(\mathrm{A} 3^{\mathrm{m}}\right)$, que ocorrem como matriz da brecha, bem como intersticiais ou como inclusões no anfibólio e na biotita/flogopita. Essas associações são caracterizadas pelo predomínio de pirrotita no domínio da brecha, e de calcopirita em pequenas zonas de cisalhamento no domínio nematoblástico. Ambas as associações
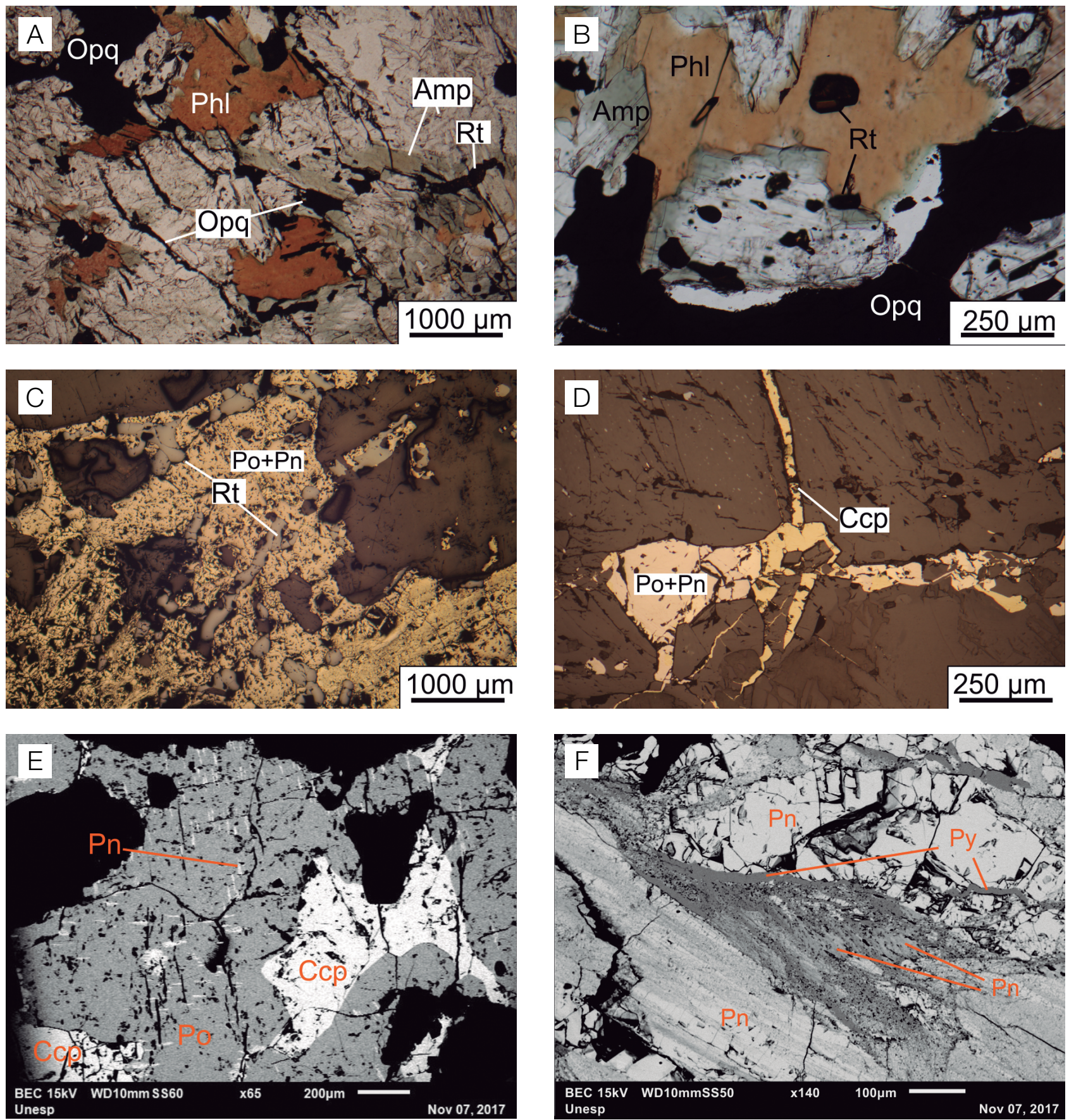

Opq: opacos; Phl: flogopita; Amp: anfibólio; Rt: rutilo; Po: pirrotita; Pn: pentlandita; Ccp: calcopirita; Py: pirita.

Figura 10. Fotomicrografias do metawebsterito": (A) textura nematoblástica definida por cristais de anfibólio, com fraturas preenchidas por minerais opacos que seccionam o anfibólio, porém não a flogopita/biotita; (B) anfibólio e flogopita/biotita com inclusões/exsoluções de rutilo e em associação com minerais opacos; (C) porção da brecha com rutilo em associação aos sulfetos; (D) fratura preenchida por calcopirita em conjunto à associação pirrotita-pentlandita-calcopirita (A2m); (E) exsoluções lamelares de pentlandita em pirrotita na $\mathrm{A} 2^{\mathrm{m}}$ (imagem BSE); (F) associação pentlandita-pirita (A4 ${ }^{\mathrm{m}}$ ) que substitui pentlandita reliquiar (imagem BSE). 
apresentam rutilo (Figura 10C) alterado para ilmenita no contato com os sulfetos.

A associação pentlandita-pirita $\left(\mathrm{A} 4^{\mathrm{m}}\right)$ na forma de intercrescimentos vermiculares que envolvem os núcleos de pentlandita reliquiar é reconhecida somente no domínio da brecha (Figura 10F). No domínio nematoblástico ocorre calcopirita confinada a veios/vênulas que seccionam cristais de rutilo, mas não os de flogopita/biotita (Figura 10A).

\section{Metagabro" $(73,05 \mathrm{~m})$}

O metagabro exibe granulometria grossa $(1-10 \mathrm{~mm})$, textura granoblástica poligonal dada por cristais anédricos a subédricos de plagioclásio (55\%) intercalados a texturas granoblástica decussada à nematoblástica, definidas por hornblenda (30\%) anédrica à subédrica. Cristais milimétricos a centimétricos de plagioclásio, em conjunto a pseudomorfos de clinopiroxênio que formam agregados de hornblenda, possivelmente representem a fase cumulus do protólito e, portanto, sugerem textura ígnea reliquiar.

Os maiores cristais de plagioclásio apresentam em seu interior inclusões microcristalinas de rutilo (2\%), ilmenita (1\%) e flogopita/biotita ( $1 \%$ ), enquanto suas bordas se encontram recristalizadas na forma de agregados poligonais mais límpidos, sem inclusões. Carbonato (2\%) e epídoto (traço) também ocorrem nos interstícios ou em fraturas nos cristais de plagioclásio.

A hornblenda geralmente possui inclusões/exsoluções microcristalinas de magnetita (traço), ilmenita e rutilo. Por vezes, forma intercrescimento simplectítico com quartzo (traço). Também se observa que flogopita/biotita anédrica substitui hornblenda, além de cristais dispersos de apatita (traço).

Os sulfetos (8\%) são representados por pirrotita-pentlan$\operatorname{dita}\left(\mathrm{A} 1^{\mathrm{m}}\right)$, pirrotita-pentlandita-calcopirita $\left(\mathrm{A} 2^{\mathrm{m}}\right)$ e, subordinadamente, pirrotita-pentlandita-calcopirita-pirita $\left(\mathrm{A}^{\mathrm{m}}\right)$, que ocorrem nos intersticiais ou como inclusões no anfibólio e na flogopita/biotita (Figuras 11A a 11D). Essas associações apresentam concentrações variadas de rutilo (Figuras $11 \mathrm{C} \mathrm{e}$ 11D), que pode estar alterado para ilmenita no contato com os sulfetos (Figura 11E). Em domínios nematoblásticos, $\mathrm{A} 2^{\mathrm{m}}$ e $\mathrm{A} 3^{\mathrm{m}}$ são caracterizadas pelo predomínio de pirrotita ou de calcopirita em relação aos outros sulfetos. Calcopirita também pode estar confinada a vênulas que podem truncar o rutilo (Figuras 11F a 11H), mas não a flogopita/biotita.

\section{Análise composicional dos sulfetos de Mangabal II}

As associações $\mathrm{A} 1^{\mathrm{m}}, \mathrm{A} 2^{\mathrm{m}}$ e $\mathrm{A} 3^{\mathrm{m}}$ encontradas no metagabro ${ }^{\mathrm{II}}$ e no metawebsterito ${ }^{\mathrm{II}}$ apresentam pirrotita com conteúdos de ferro entre 60,7 e $62,1 \%$, e pentlandita com conteúdos de níquel de 35,9 a $40 \%$. A calcopirita da $\mathrm{A} 2^{\mathrm{m}}$ e da $\mathrm{A} 3^{\mathrm{m}}$ mostra conteúdos de cobre entre 34,3 e $36 \%$, enquanto a pirita da $\mathrm{A} 3^{\mathrm{m}}$ apresenta conteúdos de ferro que varia de 46,7 a 48,9\%.
A associação $\mathrm{A} 4^{\mathrm{m}}$, encontrada somente no metawebsterito"I , apresenta pentlandita com conteúdos de níquel entre 15 e $32,8 \%$ e pirita com conteúdos de ferro de 46,5 a $48,1 \%$. Os conteúdos de níquel abaixo de $20 \%$ evidenciam a existência de fases de transição entre a pentlandita e a pirita. A calcopirita e a pirita venulares mostram conteúdos de cobre de 35 a $36 \%$ e de ferro entre 45,8 e $47 \%$, respectivamente.

A pentlandita da $\mathrm{A} 1^{\mathrm{m}}$, da $\mathrm{A} 2^{\mathrm{m}}$, da $\mathrm{A} 3^{\mathrm{m}}$ e da $\mathrm{A} 4^{\mathrm{m}}$ exibe correlação negativa entre os conteúdos de níquel e enxofre e entre níquel e ferro (Figura 12A), enquanto a calcopirita da $\mathrm{A} 2^{\mathrm{m}}$ e da $\mathrm{A} 3^{\mathrm{m}}$ mostra fraca correlação negativa entre os conteúdos de cobre e enxofre, mas não apresenta correlação entre os conteúdos de cobre e ferro (Figura 12B).

\section{DISCUSSÃO}

\section{Origem dos sulfetos de Mangabal I}

\section{Associações A1, A2 e bornita}

As associações A1 e A2 foram as únicas descritas no lherzolito', que apesar de apresentar textura coronítica compatível às fácies granulito (ver Candia, 1983; Candia et al., 1991), melhor preserva a textura cumulática do protólito ígneo. Nesse litotipo, pirrotita-pentlandita (A1) e pirrotita-pentlandita-calcopirita (A2) formam glóbulos de sulfetos intercumulus (Figura 3B), com predomínio de pirrotita e pentlandita granulares e calcopirita subordinada. Bornita substitui parcialmente alguns cristais de pirrotita ao longo de planos de fraqueza interna $\mathrm{e}$ fraturas (Figura 3D). A mineralogia e a textura dessas associações são típicas de sulfetos derivados do monosulphide solid solution (MSS) (Naldrett, 2004; Lightfoot, 2017). O intercrescimento entre calcopirita e pentlandita, bem como substituições por bornita, também sugere a formação de intermediate solid solution (ISS) ou fases sulfetadas enriquecidas em cobre no decorrer do estágio ígneo do complexo (Ballhaus et al., 2001). Dessa forma, sugere-se que A1, A2 e bornita sejam de origem ígnea e, portanto, relacionadas a processos de segregação magmática de fundidos sulfetados imiscíveis ocorridos em Mangabal I.

\section{Associações $A 2^{m}$ e $A 3^{m}$}

As associações pirrotita-pentlandita-calcopirita $\left(\mathrm{A} 2^{\mathrm{m}}\right) \mathrm{e}$ pirrotita-pentlandita-calcopirita-pirita $\left(\mathrm{A} 3^{\mathrm{m}}\right)$ encontradas no meta-olivina-ortopiroxenito ${ }^{\mathrm{I}}$, no metagabronorito ${ }^{\mathrm{I}}$ e no metagabro ${ }^{\mathrm{I}}$, diferem-se das associações A1 e A2 reconhecidas no lherzolito , pois apresentam maiores proporções de calcopirita e constituem agregados intersticiais na paragênese de fácies anfibolito (Figuras 4A, 4B, 5B e 5C). $\mathrm{A}^{\mathrm{m}} \mathrm{e} \mathrm{A} 3^{\mathrm{m}}$, em relação a A1 e A2, apresentam pirrotita empobrecida em 

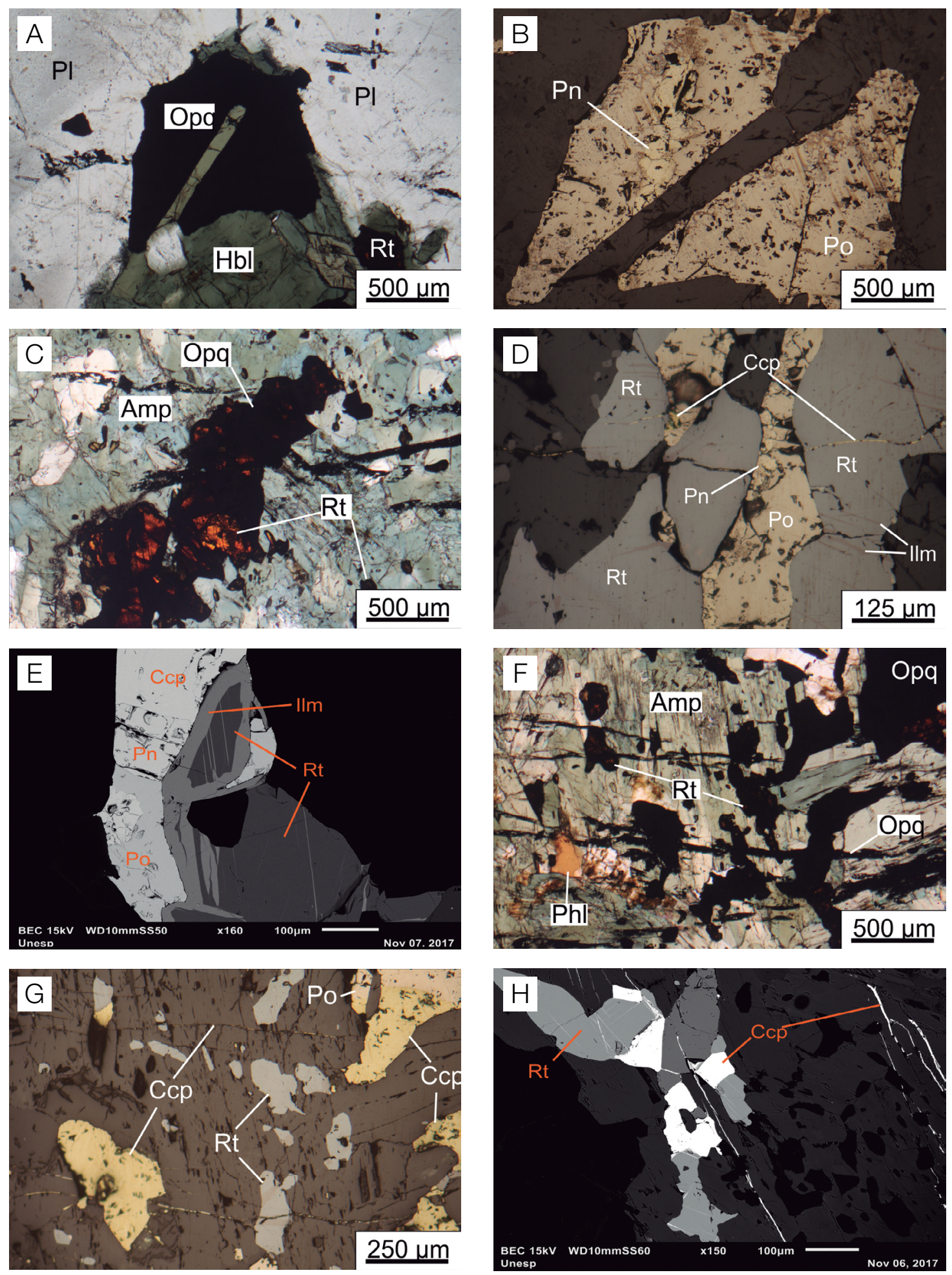

Pl: plagioclásio; Opq: opacos; Hbl: hornblenda; Rt: rutilo; Pn: pentlandita; Po: pirrotita; Amp: anfibólio; Ccp: calcopirita; llm: ilmenita; Phl: flogopita.

Figura 11. Fotomicrografias do metagabro": (A) minerais opacos seccionados por hornblenda; (B) minerais opacos anteriores representados por pirrotita-pentlandita $\left(A 1^{\mathrm{m}}\right)$; $(\mathrm{C})$ rutilo e minerais opacos em meio ao anfibólio; (D) concentração anterior constituída de pirrotita-pentlandita-calcopirita $\left(\mathrm{A} 2^{\mathrm{m}}\right)$ em equilíbrio com rutilo. Vênulas de calcopirita se prolongam da $A 2^{m}$ e truncam o rutilo; (E) detalhe de borda de ilmenita em rutilo no contato com os sulfetos (imagem BSE); (F) fraturas preenchidas por opacos e que seccionam anfibólio e rutilo; $(G)$ minerais opacos anteriores constituídos de $A 2^{m}$ e calcopirita; $(\mathrm{H})$ fraturas preenchidas por calcopirita que truncam cristais de rutilo (imagem BSE). 
ferro, pentlandita enriquecida em níquel e empobrecida em ferro, calcopirita enriquecida em cobre e empobrecida em ferro (Figura 7). $\mathrm{A} 2^{\mathrm{m}}$ e $\mathrm{A} 3^{\mathrm{m}}$ também apresentam correlações entre níquel e enxofre na pentlandita e entre cobre e enxofre na calcopirita, distintas da pentlandita e da calcopirita da $\mathrm{A} 1$ e da A2 (Figura 7). Esses aspectos indicariam, portanto, que $\mathrm{A} 2^{\mathrm{m}}$ e $\mathrm{A} 3^{\mathrm{m}}$ teriam se formado por processos distintos da A1 e da A2.

Associações de sulfetos derivadas do MSS são inicialmente enriquecidas em ferro, e com o progresso da cristalização e rebaixamento da temperatura, tornam-se gradativamente mais enriquecidas em níquel e cobre e empobrecidas em ferro (Lightfoot, 2017). A precipitação de pirita ígnea a partir de magmas/líquidos sulfetados imiscíveis e relativamente enriquecidos em enxofre (Naldrett, 2004; Djon e Barnes, 2012), bem como a precipitação de pequena quantidade de rutilo intercumulus, também tem sido descrita em complexos máfico-ultramáficos, a exemplo do Great Dyke no Zimbábue, África (Oberthuer et al., 1997).

Em contrapartida, $\mathrm{A}^{2}{ }^{\mathrm{m}} \mathrm{e} \mathrm{A} 3^{\mathrm{m}}$ ocorrem em equilíbrio com anfibólios e rutilo da paragênese anfibolítica (ver Candia, 1983; Candia e Girardi, 1991), indicativo, portanto, de que as diferenças mineralógicas e químicas acima apontadas foram provocadas pelo metamorfismo. Essa interpretação é suportada também por $\mathrm{A} 3^{\mathrm{m}}$ constituir a matriz de brecha composta de clastos do metagabronorito (Figuras 6A e 6B),
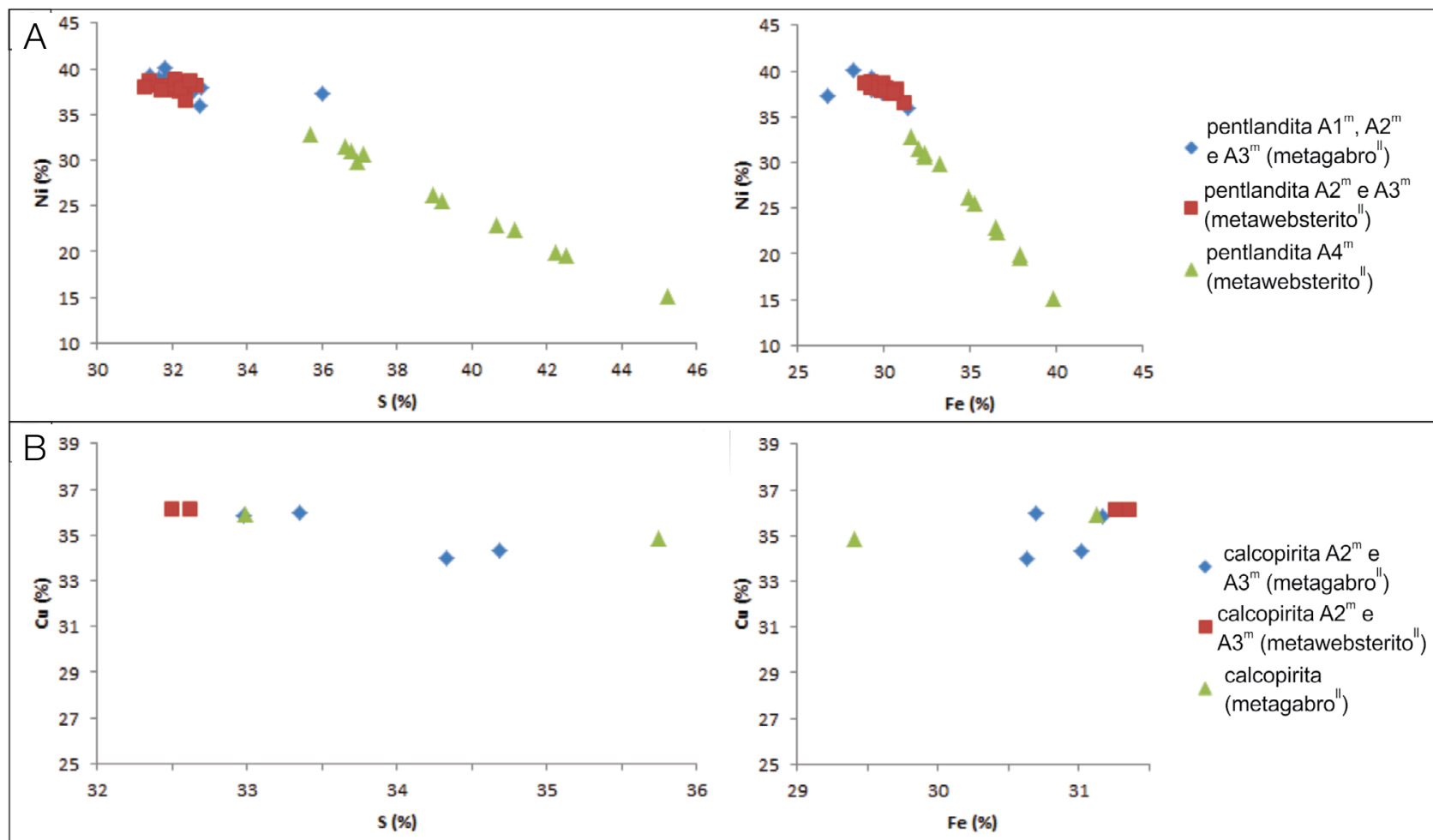

- calcopirita $A 2^{m}$ e

calcopirita $\mathrm{A} 2^{\mathrm{m}} \mathrm{e}$

A3 ${ }^{m}$ (metawebsterito")

calcopirita

(metagabro")
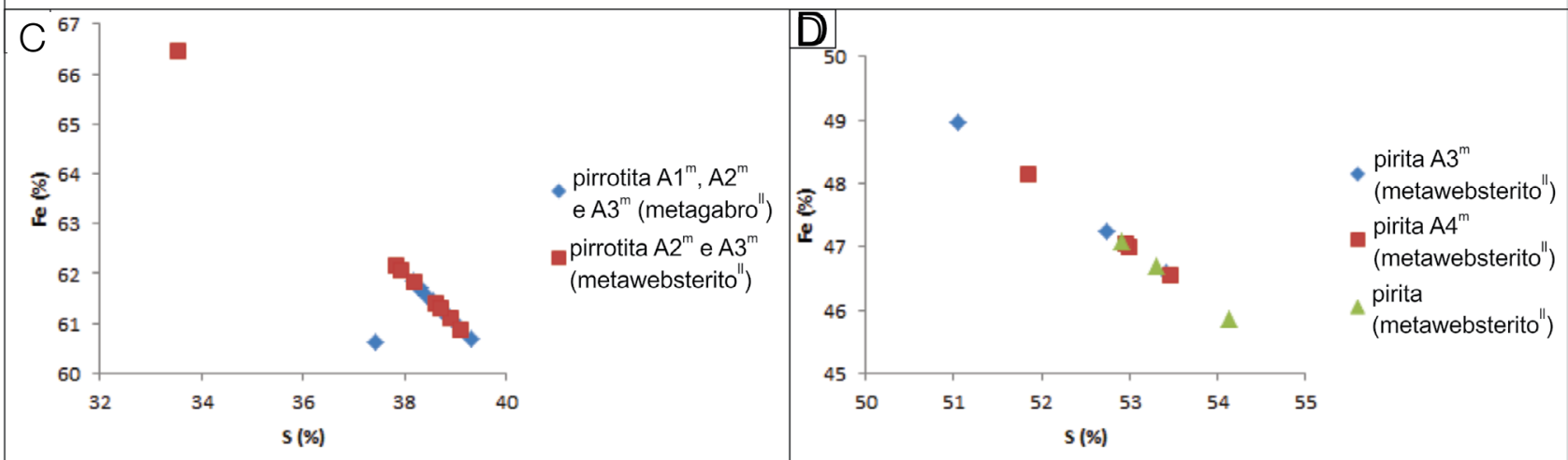

Figura 12. Diagramas binários de correção linear entre os conteúdos de níquel, ferro e enxofre na pentlandita; cobre, ferro e enxofre na calcopirita; e ferro e enxofre na pirrotita e pirita, observados nas associações sulfetadas de Mangabal II. 
ilustrativa de que essa associação representa uma fase de remobilização de sulfetos, possivelmente ocorrida no decorrer do metamorfismo das rochas do complexo. Nessa associação, calcopirita concentra-se ao redor de cristais euédricos de pirita (Figuras 5C e 6B), indicando que os sulfetos foram submetidos à deformação com posterior reprecipitação da calcopirita em zonas de menor pressão (Selkman, 1983). No mais, concentrações expressivas de rutilo associadas a sulfetos de $\mathrm{Ni}-\mathrm{Cu}$ são geralmente atribuídas a processos metamórficos, hidrotermais ou de remobilização de sulfetos ígneos preexistentes (Nesbitt e Kelly, 1980; Nesbitt, 1982; Mohr e Newton, 1983; Kontny et al., 1997; Casquet et al., 2001; Santos-e-Silva, 2015).

A coexistência entre ilmenita e rutilo nos litotipos de Mangabal indica fugacidades de enxofre moderadas durante o metamorfismo (Candia, 1983). Entretanto, observa-se que próximo às associações de sulfetos ocorre amplo predomínio de rutilo (Figuras 5B a 5D), o que sugere aumento na fugacidade de enxofre controlada pela presença de sulfetos (e.g., Nesbitt, 1982; Mohr e Newton, 1983). Candia (1983) estima que as fugacidades de oxigênio foram baixas durante o metamorfismo dos complexos, e aponta que a presença de rutilo refletiria aumento na fugacidade de enxofre. Esse aspecto, aliado à ausência de zonas de alteração (mudanças mineralógicas) ao redor das associações de sulfetos, indica que eles teriam se comportado isoquimicamente quanto aos conteúdos de enxofre, ou seja, o aumento da $f_{\mathrm{S} 2}$ deve ter ocorrido por conta da liberação de enxofre das associações sulfetadas, com a geração de um fluido metamórfico-hidrotermal aquo-carbônico não reativo às fases silicatadas das encaixantes (e.g., Craig e Vokes, 1993), com consequente precipitação restrita de minerais carbonáticos.

A formação da associação $\mathrm{A} 3^{\mathrm{m}}$, que contém pirita, também pode ser explicada por transformações isoquímicas quanto aos conteúdos de ferro, com seu empobrecimento nos sulfetos preexistentes, para posterior formação de pirita durante o retrometamorfismo. Nesse caso, a pirrotita pode se submeter à oxidação e se reprecipitar na forma de pirita e carbonatos (Hall, 1986), com liberação de $\mathrm{S}^{2-}$ que, em conjunto ao ferro previamente liberado, precipita na forma de pirita (Craig e Vokes, 1993). Isso corrobora com a existência de pirrotita, pentlandita e calcopirita relativamente empobrecidas em ferro na associação $\mathrm{A} 3^{\mathrm{m}}$ (Figura 7). A associação $\mathrm{A} 2^{\mathrm{m}}$, por sua vez, não apresenta pirita, o que indica a possibilidade do consumo do ferro previamente liberado para a geração dos Fe-silicatos metamórficos e das fases sulfetadas tardias. Estudos prévios demonstram que no metamorfismo progressivo, por exemplo, pirita tende a formar pirrotita a partir da substituição da pirita, com consequente rebaixamento da $f_{\mathrm{S} 2}$ e dos silicatos empobrecidos em ferro. Esse processo pode ser expresso pela reação pirita + silicato rico em ferro $\Leftrightarrow$ pirrotita + silicato pobre em ferro (Bachinski, 1976). O particionamento do ferro entre sulfetos e silicatos durante os reequilíbrios metamórficos não é evidente nos litotipos de Mangabal, visto que não foram observadas mudanças mineralógicas entre os silicatos próximos à associação com pirita $\left(\mathrm{A}^{\mathrm{m}}\right)$ e sem pirita $\left(\mathrm{A} 2^{\mathrm{m}}\right)$. Dessa forma, dados de química mineral são necessários para testar essa hipótese.

$\mathrm{O}$ fato de a $\mathrm{A} 2^{\mathrm{m}}$ e a $\mathrm{A} 3^{\mathrm{m}}$ estarem associadas a paragêneses hidratadas (anfibólios, biotita/flogopita), bem como a presença local de carbonato nos litotipos hospedeiros, evidencia a presença de fluidos metamórficos aquo-carbônicos $\left(\mathrm{H}_{2} \mathrm{O}-\mathrm{CO}_{2}\right)$ reduzidos. Candia (1983) estima que fluidos metamórficos com temperaturas de $\sim 700^{\circ} \mathrm{C}$ e pressões variadas de $\mathrm{H}_{2} \mathrm{O}$ e $\mathrm{CO}_{2}$ controlaram os reequilíbrios mineralógicos durante o metamorfismo dos complexos Mangabal I e Mangabal II. Nessas condições de fluido e durante o resfriamento associado ao retrometamorfismo, podem ocorrer tanto transformações isoquímicas locais (como perda parcial de ferro e enxofre da pirrotita para a formação de pirita) quanto transformações que envolvam a dissolução, a remobilização e a reprecipitação de sulfetos em razão de processos deformacionais ou da interação com fluidos metamórficos (Gilligan e Marshall, 1987; Plimer, 1987). Interpreta-se que ambos os mecanismos podem ter atuado em Mangabal I e as diferenças na $f_{\mathrm{s} 2}$ possivelmente tenham controlado a precipitação ou a ausência de pirita $\mathrm{e}$ rutilo nas associações mineralógicas.

\section{Calcopirita, associação $A 4^{m}$ e pirita}

A ocorrência de núcleos de pentlandita granular $\left(\mathrm{da} \mathrm{A} 2^{\mathrm{m}}\right.$ e da $\mathrm{A} 3^{\mathrm{m}}$ ) no interior dos intercrescimentos vermiculares entre pentlandita e pirita $\left(\mathrm{A} 4^{\mathrm{m}}\right)$, indica que $\mathrm{A} 4^{\mathrm{m}}$ se formou pela substituição de $\mathrm{A} 2^{\mathrm{m}} \mathrm{e}$ de $\mathrm{A} 3^{\mathrm{m}} \mathrm{e}$, portanto, representa uma fase posterior. Lorand e Alard (2011) descrevem intercrescimentos semelhantes em peridotito da região dos Pirineus (França) e demonstram que a associação pentlandita-pirita é estável pela reação dos sulfetos ígneos preexistentes com fluidos ricos em enxofre, possivelmente provenientes das rochas metamórficas encaixantes. Da mesma forma, a coexistência entre pirita e pentlandita relativamente enriquecida em enxofre (Figura 7A) exige a adição de enxofre no sistema, possivelmente incorporado pelo fluido metamórfico (independentemente de sua proveniência), tal como anteriormente discutido.

$\mathrm{O}$ fato de as vênulas de calcopirita se prolongarem de $\mathrm{A} 2^{\mathrm{m}}$ e seccionarem cristais de anfibólio, ilmenita e rutilo (Figura 4D) é indício de que a calcopirita teria se formado a partir da remobilização da $\mathrm{A} 2^{\mathrm{m}}$. No entanto, não foram observadas vênulas de calcopirita seccionando $\mathrm{A} 2^{\mathrm{m}}$, indicativo, portanto, de certa contemporaneidade entre essas fases. As vênulas de pirita, por sua vez, prolongam-se da associação $\mathrm{A} 4^{\mathrm{m}}$ e seccionam o anfibólio, a ilmenita e o rutilo 
(Figura 6D), bem como as associações $\mathrm{A} 2^{\mathrm{m}} \mathrm{e} \mathrm{A} 3^{\mathrm{m}}$ (Figura 6F), sugerindo certa contemporaneidade entre a $\mathrm{A} 4^{\mathrm{m}}$ e a pirita. Os aspectos texturais anteriormente mencionados indicam que a formação da calcopirita antecede a formação da $\mathrm{A} 4^{\mathrm{m}}$ e da pirita, embora todas essas fases sulfetadas pareçam ter ocorrido dentro do intervalo de metamorfismo imposto ao complexo, visto a inexistência de vênulas de calcopirita ou pirita que seccionassem a flogopita/biotita. A precipitação de calcopirita e de pirita em planos de fratura (Figuras 4D, 6D a 6F) indica que essas remobilizações são contemporâneas a posteriores à fase (ou fases) de deformação rúptil, possivelmente relacionada à exumação do complexo ao final do Ciclo Brasiliano (e.g., Hasui, 2010).

\section{Origem das associações sulfetadas de Mangabal II}

\section{Associações $A 1^{m}, A 2^{m}$ e $A 3^{m}$}

As associações pirrotita-pentlandita $\left(\mathrm{A} 1^{\mathrm{m}}\right)$, pirrotita-pentlandita-calcopirita $\left(\mathrm{A} 2^{\mathrm{m}}\right)$ e pirrotita-pentlandita-calcopirita-pirita $\left(\mathrm{A} 3^{\mathrm{m}}\right)$ mostram características texturais, mineralógicas e químicas semelhantes às associações $\mathrm{A} 2^{\mathrm{m}} \mathrm{e} \mathrm{A} 3^{\mathrm{m}}$ reconhecidas em Mangabal I (Figuras 9 a 12), e, portanto, sugere-se que foram formadas por processos semelhantes desenvolvidos durante o metamorfismo regional dos complexos.

No metawebsterito ${ }^{\mathrm{II}}$ e no metagabro ${ }^{\mathrm{II}}$, alguns cristais de rutilo em contato com as associações $\mathrm{A} 1^{\mathrm{m}}, \mathrm{A} 2^{\mathrm{m}} \mathrm{e} \mathrm{A} 3^{\mathrm{m}}$ apresentam leve desequilíbrio com consequente geração de ilmenita (Figura 11G). Esse processo, entretanto, não foi observado em Mangabal I. Esse desequilíbrio pode ser ilustrado pela reação metamórfica $\mathrm{FeTiO}_{3}$ (ilmenita) $+0.5 \mathrm{~S}_{2}$ ó FeS (pirrotita) $+\mathrm{TiO}_{2}$ (rutilo) $+0.5 \mathrm{O}_{2}$ (Kontny et al., 1997; Mohr; Newton, 1983; Nesbitt, 1982), a qual provocou a liberação de enxofre dos sulfetos com consequente formação de sulfetos, entretanto de origem metamórfico-hidrotermal.

\section{Calcopirita, associação $A 4^{m}$ e pirita}

A associação pentlandita-pirita $\left(\mathrm{A} 4^{\mathrm{m}}\right)$ apresenta características texturais semelhantes à $\mathrm{A} 4^{\mathrm{m}}$ descrita em Mangabal I (Figura 10F), e, portanto, indicativas de origem metamórfica. A pentlandita da $\mathrm{A} 1^{\mathrm{m}}$, da $\mathrm{A} 2^{\mathrm{m}}$, da $\mathrm{A} 3^{\mathrm{m}}$ e da $\mathrm{A} 4^{\mathrm{m}}$ mostra correlações negativas tanto entre os conteúdos de níquel e enxofre quanto entre os conteúdos de níquel e ferro (Figura 12A). Essa relação mostra que a pentlandita da $\mathrm{A} 4^{\mathrm{m}}$ é mais enriquecida em ferro e enxofre em relação às demais. A presença de pentlandita gradativamente enriquecida em enxofre em coexistência à pirita da $\mathrm{A} 4^{\mathrm{m}}$ também evidencia a introdução de enxofre no sistema.

As vênulas compostas de calcopirita e/ou pirita possuem características semelhantes às respectivas vênulas descritas em Mangabal I, as quais seccionam os silicatos da paragênese anfibolítica (Figuras 10D, 10F, 11F a 11H), mas não a flogopita/biotita (Figura 10A). Essas vênulas são, portanto, contemporâneas a posteriores a processos de deformação rúptil ocorridas durante o metamorfismo dos complexos.

\section{CONCLUSÃO}

Para os complexos máfico-ultramáficos Mangabal I e Mangabal II, sugere-se uma sequência similar de mineralização, que inclui:

- Formação de minério ígneo intercumulus, em glóbulos constituídos das associações pirrotita-pentlandita (A1) e pirrotita-pentlandita-calcopirita (A2). Também ocorre a formação de bornita, possivelmente a partir de líquidos residuais imiscíveis ricos em cobre, oriundos da fase ígnea;

- Transformação química, mineralógica e remobilização do minério ígneo preexistente por processos tectono-metamórficos, com a formação das associações pirrotita-pentlandita $\left(\mathrm{A} 1^{\mathrm{m}}\right)$, pirrotita-pentlandita-calcopirita $\left(\mathrm{A} 2^{\mathrm{m}}\right)$ e pirrotita-pentlandita-calcopirita-pirita $\left(\mathrm{A} 3^{\mathrm{m}}\right)$ em equilíbrio com rutilo e relativamente enriquecidas em níquel e cobre, porém empobrecidas em ferro;

- Formação de calcopirita na forma de vênulas a partir da remobilização das associações anteriores, possivelmente durante o intervalo metamórfico dos complexos;

- Formação da associação pentlandita-pirita $\left(\mathrm{A} 4^{\mathrm{m}}\right)$ na forma de intercrescimentos vermiculares e formação de pirita na forma de vênulas a partir da substituição parcial das associações anteriores pela interação com fluidos metamórficos aquo-carbônicos ricos em enxofre, no decorrer do metamorfismo dos complexos.

Quanto à mineralogia, à textura e aos conteúdos de metais base, é nítido que as associações de sulfetos hospedadas nos litotipos intensamente metamorfisados são similares tanto em Mangabal I quanto em Mangabal II. Em contrapartida, essas associações de sulfetos diferem-se das associações encontradas no litotipo de Mangabal I que preserva a textura cumulática (ígnea) do protólito. Dessa forma, sugere-se que os processos tectono-metamórficos relacionados à orogenia brasiliana, superpostos às rochas de ambos os complexos, teriam transformado substancialmente as características originais dos sulfetos ígneos e contribuíram para sua remobilização e reprecipitação. Novos trabalhos de petrografia, química mineral e análises isotópicas que venham a abranger um maior número de amostras são encorajados para um entendimento mais completo e sistemático quanto à origem dos processos mineralizantes ocorridos em Mangabal I e Mangabal II. 


\section{AGRADECIMENTOS}

Os autores agradecem ao professor Dr. João Batista Guimarães Teixeira e ao revisor anônimo os comentários e as sugestões que foram essenciais para o enriquecimento do trabalho. Também de grande importância foi a assistência do professor Dr. George Luiz Luvizotto junto ao laboratório de Microscopia Eletrônica de Varredura do Departamento de Petrologia e Metalogenia (DPM) da Unesp, Rio Claro.

\section{REFERÊNCIAS}

Almeida, F. F. M., Hasui, Y., Brito Neves, B. B., Fuck, R. A. (1981). Brazilian Structural Provinces : An Introduction. Earth-Science Reviews, 17(1-2), 1-29. https://doi. org/10.1016/0012-8252(81)90003-9

Augustin, C. T., Della Giustina, M. E. S. D. (2019). Geology and metamorphism of the neoproterozoic Mangabal complex: An example of Ni-Cu-PGE mineralized intrusion in the Goiás Magmatic Arc, central Brazil. Journal of South American Earth Sciences, 90, 504-519. https://doi.org/10.1016/j.jsames.2018.12.013

Bachinski, D. J. (1976). Metamorphism of cupriferous iron sulfide deposits, Notre Dame Bay, Newfoundland. Economic Geology, 71(2), 443-452. https://doi.org/10.2113/ gsecongeo.71.2.443

Ballhaus, C., Tredoux, M., Spath, A. (2001). Phase Relations in the Fe-Ni-Cu-PGE-S System at Magmatic Temperature and Application to Massive Sulphide Ores of the Sudbury Igneous Complex. Journal of Petrology, 42(10), 1911-1926. https://doi.org/10.1093/petrology/42.10.1911

Brito Neves, B. B., Fuck, R. A., Pimentel, M. M. (2014). The Brasiliano collage in South America : a review. Brazilian Journal of Geology, 44(3), 493-518. https://doi.org/10.5327/ Z2317-4889201400030010

Candia, M. A. F. (1983). Petrologia dos complexos máficoultramáficos de Mangabal I e Mangabal II, Sanclerlândia, Goiás. Tese (Doutorado). São Paulo: Instituto de Geociências - USP. https://doi.org/10.11606/T.44.1983. tde-15092015-133104

Candia, M. A. F., Girardi, V. A. V. (1991). A transição gabroanfibolito nos complexos Mangabal I e II, Sanclerlândia, Goiás. Boletim IG-USP. Série Cientifica, 22, 1-14. http:// dx.doi.org/10.11606/issn.2316-8986.v22i0p1-14

Candia, M. A. F., Schultz-Gütller, R. A., Gaspar, J. C. (1991). Formação metamórfica de coronas em rochas dos complexos máfico-ultramáficos de Mangabal I e II, Goiás. Revista Brasileira de Geociências, 21(4), 305-316.

Casquet, C., Galindo, C., Tornos, F., Roldán, F.V., Canales, A. (2001). The Aguablanca $\mathrm{Cu}-\mathrm{Ni}$ ore deposit (Extremadura, Spain), a case of synorogenic orthomagmatic mineralization: age and isotope composition of magmas ( $\mathrm{Sr}, \mathrm{Nd}$ ) and ore (S). Ore Geology Reviews, 18(3-4), 237-250. https://doi. org/10.1016/S0169-1368(01)00033-6

Craig, J. R., Vokes, F. M. (1993). The metamorphism of pyrite and pyritic ores: an overview. Mineralogical Magazine, 57(386), 3-18. https://doi.org/10.1180/ minmag.1993.057.386.02

Della Giustina, M. E. S. D., Pimentel, M. M., Ferreira Filho, C. F., Hollanda, M. H. B. M. (2011). Dating coeval mafic magmatism and ultrahigh temperature metamorphism in the Anápolis - Itauçu Complex, Central Brazil. Lithos, 124(12), 82-102. https://doi.org/10.1016/j.lithos.2010.11.004

Djon, M. L. N., Barnes, S. (2012). Changes in sulfides and platinum-group minerals with the degree of alteration in the Roby, Twilight, and High Grade Zones of the Lac des Iles Complex , Ontario, Canada. Mineralium Deposita, 47(8), 875-896. https://doi.org/10.1007/s00126-012-0401-z

Gilligan, L. B., Marshall, B. (1987). Textural evidence for remobilization in metamorphic environments. Ore Geology Reviews, 2(1-3), 205-229. https://doi. org/10.1016/0169-1368(87)90029-1

Gioia, S. M. C. L. (1997). Preparação da Metodologia Sm-Nd para Datação de Amostras Geológicas e sua Aplicação em Rochas das Areas de Firminópolis, Fazenda Nova e Americano do Brasil-GO. Dissertação (Mestrado). Brasília: Instituto de Geociências - UNB.

Hall, A. (1986). Pyrite-pyrrhotine redox reactions in nature. Mineralogical Magazine, 50(356), 223-229. https://doi. org/10.1180/minmag.1986.050.356.05

Hasui, Y. (2010). A grande colisão pré-cambriana do sudeste brasileiro e a estruturação regional. Geociências, 29(2), 141-169.

Kontny, A., Friedrich, G., Behr, H. J., de Wall, H., Horn, E. E., Möller, P., Zulauf, G. (1997). Formation of ore minerals in metamorphic rocks of the German continental deep drilling site (KTB). Journal of Geophysical Research, 102(B8), 18323-18336. https://doi.org/10.1029/96JB03395

Laux, J. H., Pimentel, M. M., Dantas, E. L., Armstrong, R., Armele, A., Nilson, A. A. (2004). Mafic magmatism 
associated with the Goiás magmatic arc in the Anicuns region, Goiás, central Brazil: Sm-Nd isotopes and new ID-TIMS and SHRIMP U-Pb data. Journal of South American Earth Sciences, 16(7), 599-614. https://doi.org/10.1016/j. jsames.2003.11.001

Laux, J. H., Pimentel, M. M., Dantas, E. L., Armstrong, R., Junges, S. L. (2005). Two neoproterozoic crustal accretion events in the Brasília belt, central Brazil. Journal of South American Earth Sciences, 18(2), 183-198. https://doi. org/10.1016/j.jsames.2004.09.003

Lightfoot, P. C. (2017). The mineral system characteristics of the Sudbury Ni-Cu-Co-PGE sulfide ore deposits. In: P. C. Lightfoot (Ed.). Nickel Sulfide Ores and Impact Melts: Origin of the Sudbury Igneous Complex (p. 296-440). Amsterdã: Elsevier.

Lightfoot, P. C., Stewart, R., Gribbin, G., Mooney, S. J. (2017). Relative contribution of magmatic and postmagmatic processes in the genesis of the Thompson Mine Ni-Co sulfide ores, Manitoba, Canada. Ore Geology Reviews, 83, 258-286. https://doi.org/10.1016/j. oregeorev.2016.12.017

Lorand, J. P., Alard, O. (2011). Pyrite tracks assimilation of crustal sulfur in Pyrenean peridotites. Mineralogy and Petrology, 101(1-2), 115-128. https://doi.org/10.1007/ s00710-010-0138-2

Mohr, D. W., Newton, R. C. (1983). Kyanite-staurolite metamorphism in sulfidic schists of the Anakkesta Formation, Great Smoky mountains, North Carolina. American Journal of Science, 283(2), 97-134. https://doi.org/10.2475/ajs.283.2.97

Mota-e-Silva, J. (2009). O Complexo Máfico-ultramáfico Acamadado de Americano do Brasil e sua mineralização de $\mathrm{Ni}$-Cu-Co. Dissertação (Mestrado). Brasília: Instituto de Geociências - UNB.

Mota-e-Silva, J., Ferreira Filho, C. F., Bühn, B., Dantas, E. L. (2011). Geology, petrology and geochemistry of the "Americano do Brasil" layered intrusion, central Brazil, and its $\mathrm{Ni}-\mathrm{Cu}$ sulfide deposits. Mineralium Deposita, 46(1), 57-90. https://doi.org/10.1007/s00126-010-0312-9

Naldrett, A. J. (2004). Magmatic Sulfide Deposits: Geology, Geochemistry and Exploration. Berlim: Springer.

Nesbitt, B. E. (1982). Metamorphic Sulfide-Silicate Equilibria in the Massive Sulfide Deposits at Ducktown, Tennessee. Economic Geology, 77(2), 364-378. https://doi.org/10.2113/ gsecongeo.77.2.364
Nesbitt, B. E., Kelly, W. C. (1980). Metamorphic Zonation of Sulfides, Oxides, and Graphite in and around the Orebodies at Ducktown, Tennesse. Economic Geology, 75(7), 10101021. https://doi.org/10.2113/gsecongeo.75.7.1010

Nilson, A. A. (1981). The nature of the Americano do Brasil Mafic-Ultramafic Complex and associated sulfide mineralization, Goiás, Brazil. Tese (Doutorado). Ontário: University of Western Ontario - UWO

Oberthuer, T., Cabri, L. J., Weiser, T. W., McMahon, G., Muller, P. (1997). Pt, Pd and other trace elements in sulfides of the main sulfide zone, Great Dyke, Zimbabwe: A reconnaissance study. The Canadian Mineralogist, 35(3), 597-609.

Pimentel, M. M., Fuck, R. A., Gioia, S. M. C. L. (2000). The Neoproterozoic Goiás magmatic arc, central Brazil: a review and new $\mathrm{Sm}-\mathrm{Nd}$ isotopic data. Brazilian Journal of Geology, 30(1), 35-39. https://doi. org/10.25249/0375-7536.2000301035039

Piuzana, D., Pimentel, M. M., Fuck, R. A., Armstrong, R. (2003a). Neoproterozoic granulite facies metamorphism and coeval granitic magmatism in the Brasilia Belt, Central Brazil: regional implications of new SHRIMP $\mathrm{U}-\mathrm{Pb}$ and Sm - Nd data. Precambrian Research, 125(3-4), 245-273. https://doi.org/10.1016/S0301-9268(03)00108-6

Piuzana, D., Pimentel, M. M., Fuck, R. A., Armstrong, R. (2003b). SHRIMP U-Pb and Sm-Nd data for the Araxá Group and associated magmatic rocks: constraints for the age of sedimentation and geodynamic context of the southern Brasília Belt, central Brazil. Precambrian Research, 125(1-2), 139-160. https://doi.org/10.1016/ S0301-9268(03)00107-4

Plimer, I. R. (1987). Remobilization in high-grade metamorphic environments. Ore Geology Reviews, 2(1-3), 231-245. https://doi.org/10.1016/0169-1368(87)90030-8

Santos-e-Silva, K. (2015). Geologia, Petrologia, Geocronologia e Mineralizações Sulfetadas do Complexo Ézio, Província Mineral do Carajás, Brasil. Dissertação (Mestrado). Brasília: Instituto de Geociências - UNB. http:// dx.doi.org/10.26512/2015.12.D.20456

Selkman, S. O. (1983). Stress and displacement distributions around pyrite grains. Economic Geology, 5(1), 47-52. https:// doi.org/10.1016/0191-8141(83)90006-8

Silva, B. V. (2012). Mapeamento geológico e petrologia dos complexos máfico-ultramáficos de Mangabal Sul e Mangabal 
Norte, região de Sanclerlândia, Goiás. Monografia (TCC). Rio Claro: Instituto de Geociências e Ciências Exatas - UNESP.

Streckeisen, A. (1976). To each plutonic rock its proper name. Earth Science Reviews, 12(1), 1-33. https://doi. org/10.1016/0012-8252(76)90052-0

Valeriano, C. M., Dardenne, M. A., Fonseca, M. A., Simões, L. S. A., Seer, H. J. (2004). A evolução tectônica da Faixa Brasília. In: V. Mantesso-Neto, A. Bartorelli, C. D. R., Carneiro, B. B., Brito-Neves (Eds.), Geologia do Continente Sul-Americano: Evolução da Obra de Fernando Flávio Marques de Almeida (p. 575-592). São Paulo: Beca.

Whitney, D. L., Evans, B. W. (2010). Abbreviations for names of rock-forming minerals. American Mineralogist, 95(1), 185-187. https://doi.org/10.2138/ am.2010.3371 